\title{
Review \\ Oxidative Stress and Lipid Mediators Modulate Immune Cell Functions in Autoimmune Diseases
}

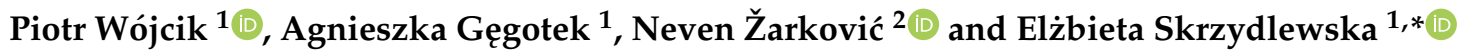 \\ 1 Department of Analytical Chemistry, Medical University of Bialystok, 15-222 Bialystok, Poland; \\ piotr.wojcik@umb.edu.pl (P.W.); agnieszka.gegotek@umb.edu.pl (A.G.) \\ 2 Laboratory for Oxidative Stress, Rudjer Boskovic Institute, 10000 Zagreb, Croatia; Neven.Zarkovic@irb.hr \\ * Correspondence: elzbieta.skrzydlewska@umb.edu.pl
}

Citation: Wójcik, P.; Gęgotek, A.;

Žarković, N.; Skrzydlewska, E.

Oxidative Stress and Lipid Mediators Modulate Immune Cell Functions in Autoimmune Diseases. Int. J. Mol. Sci 2021, 22, 723. https://doi.org/ 10.3390/ijms22020723

Received: 27 November 2020 Accepted: 11 January 2021 Published: 13 January 2021

Publisher's Note: MDPI stays neutral with regard to jurisdictional clai$\mathrm{ms}$ in published maps and institutional affiliations.

Copyright: (C) 2021 by the authors. Licensee MDPI, Basel, Switzerland. This article is an open access article distributed under the terms and conditions of the Creative Commons Attribution (CC BY) license (https:// creativecommons.org/licenses/by/ $4.0 /)$.

\begin{abstract}
Autoimmune diseases, including psoriasis, systemic lupus erythematosus (SLE), and rheumatic arthritis (RA), are caused by a combination of environmental and genetic factors that lead to overactivation of immune cells and chronic inflammation. Since oxidative stress is a common feature of these diseases, which activates leukocytes to intensify inflammation, antioxidants could reduce the severity of these diseases. In addition to activating leukocytes, oxidative stress increases the production of lipid mediators, notably of endocannabinoids and eicosanoids, which are products of enzymatic lipid metabolism that act through specific receptors. Because the anti-inflammatory CB2 receptors are the predominant cannabinoid receptors in leukocytes, endocannabinoids are believed to act as anti-inflammatory factors that regulate compensatory mechanisms in autoimmune diseases. While administration of eicosanoids in vitro leads to the differentiation of lymphocytes into T helper 2 (Th2) cells, eicosanoids are also necessary for the different0iation of Th1 and Th17 cells. Therefore, their antagonists and/or the genetic deletion of their receptors abolish inflammation in animal models of psoriasis-RA and SLE. On the other hand, products of non-enzymatic lipid peroxidation, especially acrolein and 4-hydroxynonenal-protein adducts, mostly generated by an oxidative burst of granulocytes, may enhance inflammation and even acting as autoantigens and extracellular signaling molecules in the vicious circle of autoimmune diseases.
\end{abstract}

Keywords: lipid mediators; endocannabinoids; ROS; prostaglandins; oxidative stress; immunity; rheumatoid arthritis; psoriasis; psoriatic arthritis; systemic lupus erythematosus

\section{Literature Review}

Autoimmune diseases are a group of diseases in which the immune system becomes activated against host cells. These diseases are serious social and medical problems affecting many people, reducing their quality of life and even lifespan. Nevertheless, despite the enormous effort put into developing an effective therapy, even the latest so-called biological therapies, which are much more effective and safer than the immunosuppressive drugs used so far, are still not able to cure but only temporarily reduce disease symptoms. Also, because these therapies modulate the immune system, they cause side effects such as susceptibility to infections [1]. This therapeutic problem may be because autoimmune diseases and their underlying pathophysiology are not fully understood. Nevertheless, it is now known that autoimmune diseases are the result of a combination of genetic and environmental factors, the latter of which are very often considered to act as "triggers" because they are not the main cause of the disease but rather help their development in already genetically susceptible individuals. This is true for the most common autoimmune diseases such as psoriasis, systemic lupus erythematosus (SLE), and rheumatoid arthritis (RA) [2-4].

Psoriasis, which affects about $3 \%$ of the population in western countries [5], has different clinical subtypes; the most common types are psoriasis vulgaris and psoriatic arthritis. Clinically, psoriasis is manifested by characteristic skin lesions, and in the case of psoriatic 
arthritis, is accompanied by pain and malfunctions of joints. Psoriasis is assumed to be a multifactorial disease, which develops in individuals that have a genetic predisposition for the onset of the disease and is further enhanced by environmental factors. This is supported by the fact that psoriasis is up to $35 \%$ more common in twins than in other people [6], being inherited in a multi-genetic way with over 40 alleles associated with psoriasis. Clinical symptoms arise from the activity of immune cells (leukocytes), while changes of leukocyte phenotype and biochemical features have been observed in not only the skin but also the blood of patients with psoriasis vulgaris [5].

Similar to psoriatic arthritis, RA is a disease whose symptoms affect joints, while some changes can also be seen in blood cells, allowing RA to be considered a systemic disease, too [4]. Synovial hyperplasia is a hallmark of the disease manifested by excessive proliferation of fibroblast-like synovial cells in the joints (driven by inflammatory cytokines), which reduces the mobility of the joints. The disease is, like other autoimmune diseases, caused by a combination of environmental and genetic factors. However, despite some similarities of symptoms, psoriatic arthritis and RA have a significantly different pathogenesis. Importantly, bacterial infections or smoking are the most important triggers for RA symptoms because these factors can lead to a pathological response of the immune system. The disease affects up to $1 \%$ of the population, particularly targeting the elderly [7].

Another autoimmune disease associated with chronic inflammation with complex, but not fully understood pathogenesis, is SLE. Although less common than psoriasis or RA, with 20-200 cases per 100,000 individuals, the course of the disease is more severe. SLE has complex symptoms that affect different tissues, including painful and swollen joints, fever, chest pain, hair loss, mouth ulcers, swollen lymph nodes, tiredness, and red rash showing systemic characteristics of the disease [8].

The most important cells for the development of autoimmune diseases seem to be lymphocytes, particularly $\mathrm{T}$ cells in both forms of psoriasis (Figure 1), and $\mathrm{T}$ and $\mathrm{B}$ cells in RA and SLE (Figure 2). In healthy individuals, T cells are responsible for the development of adaptive immunity and modulation of the immune system. The $T$ cells that have not been previously activated are denoted as naive lymphocytes, which are activated by monocytes and dendritic cells in a process of antigen presentation. Dendritic cells can only activate naive lymphocytes, while monocytes are able to activate also memory lymphocytes [9]. Usually, dendritic cells recognize pathogens by Toll-like receptors (TLRs) before they phagocytose them. Pathogens are proteolyzed and their fragments (i.e., antigens) are complexed by major histocompatibility complex II (MHC II) molecules and transported to the cell surface where they are presented. Antigens presented by MHC II are recognized by T-cell receptors (TCRs) and cluster of differentiation 4 (CD4) receptors on Th lymphocytes. Moreover, costimulatory molecules such as CD80 or CD86 are also present on dendritic cells [10]. The presence of both MHC II-presented antigen and costimulatory molecules is necessary for the activation of Th lymphocytes. TCRs are characterized by a high degree of diversity, and only lymphocytes that express TCRs specific to particular antigens are activated upon their encounter.

It has been suggested that the selectivity of Toll Like Receptors (TLRs) is disturbed in psoriasis where dendritic cells are activated despite the absence of pathogens to be eliminated. Two specific TLRs, TLR-9 and TLR-7, are activated by DNA and RNA, respectively [11]. However, they are activated by "foreign" nucleic acids and not by the own human nucleic acids. Human DNA is normally digested by deoxyribonucleases (DNases) and a lack of DNase 1 is an important factor for the onset of autoimmune diseases [12]. Moreover, TLR-7 and TLR-9 are endosomal receptors so they can only be activated by DNA or RNA that has been taken up by cells through endocytosis. Moreover, TLR-7 can only be activated by double-stranded RNA, which is typical for viruses, not for mammalian genomic material [13]. In the case of psoriasis, large amounts of the antimicrobial peptide LL-37 are produced (mainly by keratinocytes). This peptide forms complexes with nucleic acids, which prevents nucleic acids from being digested, but such complexes undergo endocytosis, activating TLRs and, consequently, dendritic cells and T lymphocytes. 


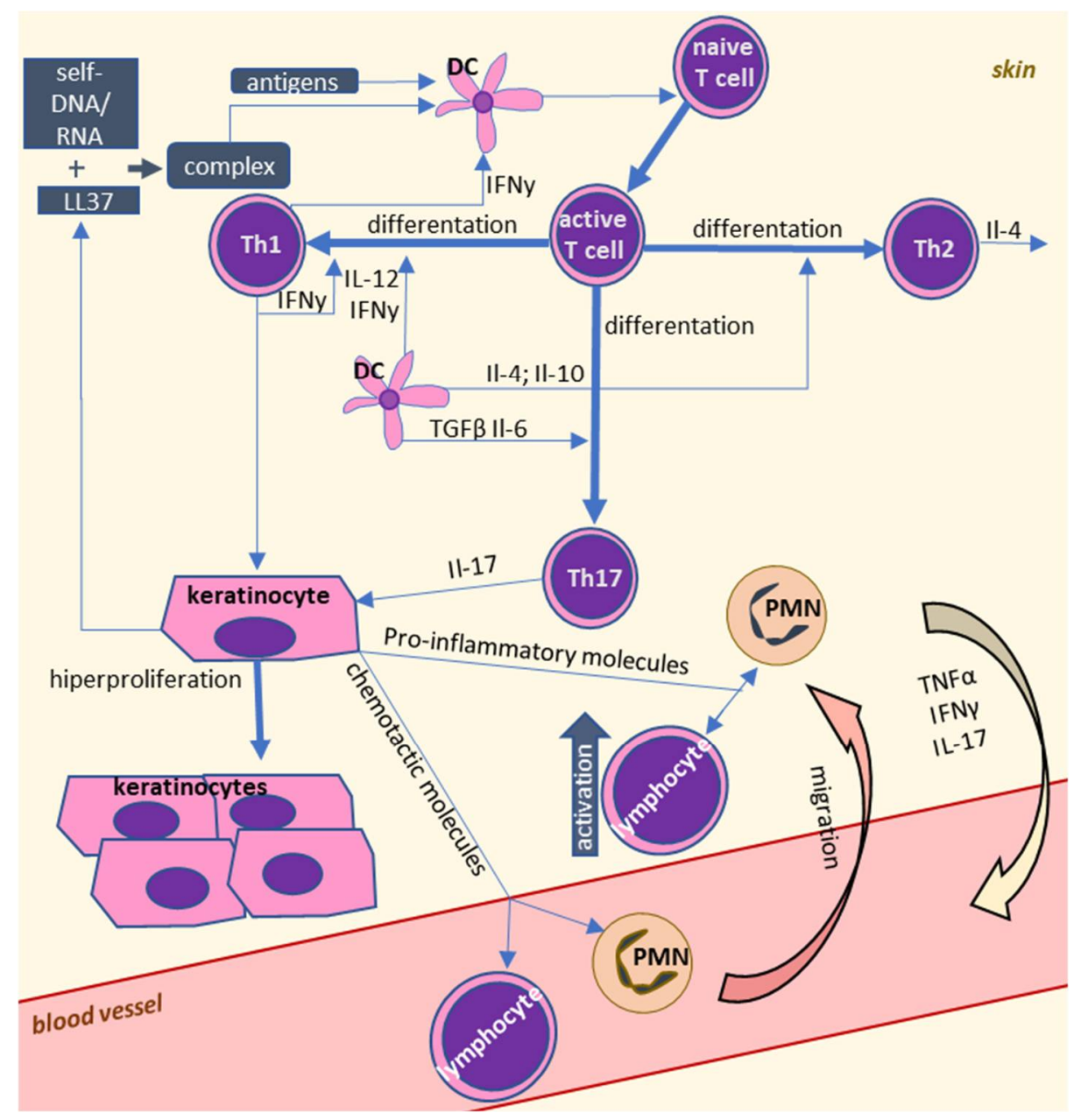

Figure 1. Cellular interactions in psoriasis. Psoriasis is characterized by abnormal interactions between leukocytes. Overactivation of dendritic cells leads to polarization of T lymphocytes into $\mathrm{T}$ helper 1 (Th1) and in consequence higher levels of pro-inflammatory factors produced by these cells, which cause proliferation of keratinocytes. Activation of granulocytes during psoriasis is important for the progression of inflammation and oxidative stress.

TLRs are also important for the development of SLE. In SLE, high TLR7 expression correlates with disease severity. Moreover, some polymorphisms in the TLR-7 gene correspond to a higher risk of SLE [14,15]. Additionally, administration of a TLR-7 agonistimiquimod-leads to systemic changes in animal models [16]. As activation of dendritic cells leads to activation of lymphocytes, these changes may cause the pro-inflammatory phenotype of lymphocytes. In RA, high expression of TLRs has been observed in synovial fibroblasts and monocytes [17]. Moreover, RNA from the synovial fluid of RA patients acts as a ligand for TLRs and leads to monocytic activation, whereas RNA from the plasma of these patients, or healthy subjects, does not [18]. Even though there is no direct evidence that RA is associated with increased expression of TLRs in dendritic cells, the presence of TLR ligands (including RNA) in the synovial fluid suggests that immune cells present in joints are activated through TLRs. Moreover, in the case of osteoarthritis, dendritic cells show higher TLR expression [19].

Autoimmune diseases are typically accompanied by a Th1/Th2 imbalance in favor of Th1, with more recent data showing that Th17 cell numbers can also increase. Th1 and Th17 cells play a role in immunity and in the development of autoimmune diseases through the production of large amounts of cytokines IFN $\gamma$ and IL-17, respectively. IFN $\gamma$, the level of which correlates with disease activity [20], stimulates monocyte activation, antigen presentation, and differentiation of lymphocytes to Th1 cells, thereby enhancing immune 
responses and inflammation [21,22]. In psoriasis vulgaris, IFN $\gamma$ is also responsible for the excessive proliferation of keratinocytes. It has been found that adding Th cell-conditioned medium to keratinocytes causes their excessive proliferation, while IFN $\gamma$ inactivation abolishes this effect [23]. Moreover, B cells are also important in the development of SLE and RA because they produce autoantibodies. In contrast to Th cells, which are mainly regulatory cells, the main biological role of $B$ lymphocytes is the production of antibodies. Activation of B cells begins when an antigen binds to a B-cell receptor (BCR). After binding, the antigen is degraded into peptide fragments in the cell and the fragments are presented on the cell surface. The antigens are then recognized by specific, previously activated Th cells. The interaction between the CD40 molecule on the surface of B lymphocytes and CD40L on T lymphocytes is necessary for B cell activation. Additionally, Th cells produce cytokines that play an important role in B cell activation [24]. After activation, B cells develop into plasma cells and produce immunoglobulin (IgM and IgG), and/or B memory cells. B cells are only activated by Th cells when both cells react to the same antigen.

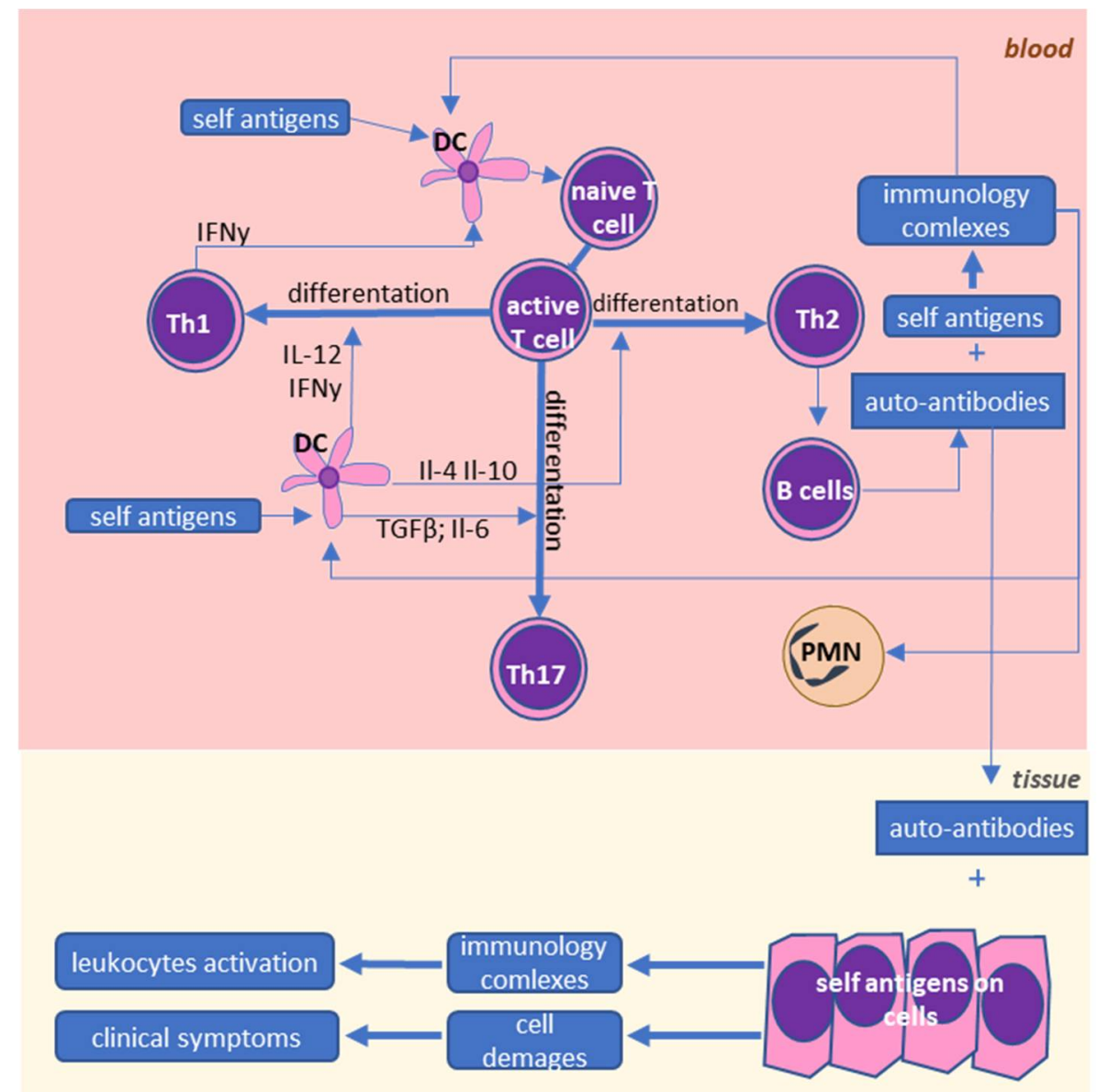

Figure 2. Cellular interactions in lupus erythematosus (SLE) and rheumatoid arthritis (RA). SLE and RA are characterized by abnormal interactions between leukocytes. Overactivation of dendritic cells leads to higher activation of different subpopulations of T lymphocytes, and in consequence, to higher levels of pro-inflammatory molecules produced by these cells. Moreover, Th2 activates B cells, which leads to the production of autoantibodies that bind to the self-antigens, in consequence leading to the destruction of tissues and further activation of the immune system.

In SLE, B cells produce several autoantibodies, including antibodies against doublestranded DNA (anti-dsDNA) and anti-nuclear antibodies (ANAs) [25]. These antibodies appear to be important in the pathogenesis of autoimmune diseases. When antibodies bind to their target, they form immune complexes, which are potent activators of immune 
cells. Moreover, levels of autoantibodies correlate with the severity of the disease and are the most important diagnostic markers for SLE. In RA, the most important antibodies are against the fragment crystallizable region (Fc region) of IgG, which is also called rheumatoid factor (RF) [26]. Diagnosis of RA is highly dependent on the presence of RF in serum. As RA has symptoms resembling other diseases (including psoriatic arthritis), its diagnosis is confirmed only if the patient is RF positive. Although autoantibodies (anti-dsDNA and ANA) may also be present in psoriatic patients, they are observed only in the minority of patients and are thus not a significant clinical feature of the disease [27].

Neutrophils also play a significant role in the development of autoimmune diseases. They are the most numerous cells among leukocytes-constituting over $50 \%$ of peripheral blood leukocytes-and are the first to react at the site of inflammation. The presence of microbes or tissue damage leads to the expression of P-selectin, E-selectin, ICAM-1, and VCAM-1 on endothelial cells. As neutrophils typically circulate in the bloodstream near blood vessel walls, they recognize and interact with these endothelial membrane molecules, which leads to their activation and migration through vessel walls in a process called diapedesis [28]. Diapedesis is additionally intensified by chemoattractants, mainly of bacterial origin, like N-formylmethionyl-leucyl-phenylalanine (fMLP) [29]. Moreover, once in tissue, neutrophils move toward microbes thanks to their ability to chemotaxis, that is, to move under the influence of chemical signals, and consequently move toward a higher concentration of the above-mentioned chemoattractants. Endogenous lipid mediators produced during inflammation, such as leukotrienes B4 (LTB4), also act as chemoattractants for neutrophils [30], increasing their recruitment to the site of inflammation.

Neutrophils also have pattern recognition receptors (PPRs), which react with pathogenassociated molecular patterns (PAMP), which are molecules not produced by human cells but by microbes, as in the case of bacterial lipopolysaccharide (LPS) and viral doublestranded RNA [31]. The main function of neutrophils is phagocytosis and elimination of pathogens. When a pathogen is phagocytosed, it is eliminated by neutrophils through oxygen-dependent or -independent mechanisms. In oxygen-dependent mechanisms, neutrophils produce large amounts of reactive oxygen species (ROS) to eliminate pathogens, whereas in oxygen-independent mechanisms, antimicrobial proteins in the granules of neutrophils digest the phagocytosed bacteria. In addition, antimicrobial substances stored in neutrophils can also be released outside in a process called degranulation, or they can be mixed with chromatin inside neutrophils and released as a network of chromatin and antimicrobial peptides in a cell death process called NETosis [32].

\subsection{Oxidative Stress}

Autoimmune diseases are usually accompanied by metabolic changes that involve the development of pro-inflammatory processes and oxidative stress. In psoriasis, redox imbalance is observed not only in skin cells but also in plasma and blood cells, including granulocytes and lymphocytes $[33,34]$. Moreover, it has also been shown that mutations in genes encoding some antioxidants, such as paraoxonase-1, correlate with the severity of the disease [35]. As a result, higher levels of oxidatively modified lipids and proteins can also be observed $[33,34,36]$. Therefore, it has been suggested that a diet rich in antioxidants should treat psoriasis. It has been found that the antioxidant astilbin reduces both the production of ROS and the proliferation of keratinocytes, suggesting the important role of ROS-induced changes in immune cells and keratinocytes [37].

Similar to psoriasis, oxidative stress is also involved in the development of SLE and RA and can be an important factor in the onset of these diseases [38,39]. In SLE, oxidative stress causes DNA damage, which leads to the production of anti-dsDNA antibodies [40]. Hence, therapy with the antioxidant-glutathione precursor $\mathrm{N}$-acetylcysteine, or with other antioxidants such as metformin, has a positive impact on the health condition of patients with SLE [41,42]. Opposite to that, smoking, which also leads to oxidative stress, is the most important risk factor in RA [43-45]. Oxidative stress may not only trigger RA but is also involved in its pathogenesis. Namely, neutrophils are known to generate large amounts 
of ROS and are the most abundant cells in the synovial fluid of RA patients where they generate higher levels of total ROS and hydroxyl radicals-the levels of which correlate with disease activity score (DAS28), which is the most common clinical factor used to determine the severity of symptoms of RA [46]. Neutrophils are also the main source of pro-oxidative molecules such as myeloperoxidase (MPO), the levels of which correlate with levels of the pro-inflammatory cytokines IL- 8 and IL-18 in RA. Standard treatment for RA leads to a decrease in levels of MPO and these cytokines, supporting the observation that inflammation and oxidative stress occur together during RA [47].

Since neutrophils generate a large amount of ROS, their activation is important for the onset of oxidative stress, which is defined as a shift in the redox balance toward oxidative reactions. As a result, ROS interact with proteins, nucleic acids, and especially lipids, causing oxidative modifications of their structure. One of the metabolically significant consequences is the peroxidation of membrane phospholipids with increased production of reactive aldehydes such as 4-HNE [48]. This leads to serious metabolic disturbances and can even lead to cell death [49]. ROS also lead to the activation of transcription factors that modulate the biosynthesis of antioxidant proteins and pro-inflammatory factors [33]. Therefore, oxidative-stress-dependent activation of transcription factors can exacerbate inflammation and activate immune cells $[33,34]$.

ROS activate transcription factors such as NF- $K \beta$ and Nrf2. The NF- $k \beta$ is activated by over 150 other factors, including cytokines (e.g., TNF- $\alpha$, TGF- $\alpha$, IL-1, IL-17), TLR receptors, DNA damaging factors (including oxidative stress), hypoxia, $\mathrm{H}_{2} \mathrm{O}_{2}$, and oxidized low density lipoproteins (LDL). In turn, NF- $k \beta$ activates the transcription of factors such as IFN- $\gamma$, IL-1, TNF- $\alpha$, TNF- $\beta$, p62, p53, etc. [50,51]. Psoriasis, both vulgaris and arthritic, as well as SLE and RA, have higher expression of NF- $\kappa \beta$ and TNF- $\alpha$, which is the product of its activity [33,34,52]. In contrast, inhibition of TNF- $\alpha$ action leads to improvement of the clinical condition of patients suffering from these diseases. Therefore TNF- $\alpha$ antagonists (adalimumab, infliximab, and etanercept) were approved by the US Federal Drug and Administration (FDA) for the treatment of psoriasis and rheumatic arthritis [53-56].

Similarly, Nuclear factor erythroid 2-like(Nrf2) expression is also enhanced in these diseases. However, the Nrf2 transcription factor, which binds to antioxidant response elements in DNA, enhances the expression of proteins responsible for defense against oxidative stress [57]. Its activation is mainly caused by ROS, which may inactivate the Nrf2 cytosol inhibitor Keap1. Under normal, unstressed conditions, Nrf2 is present in cells in a complex with Keap1, determined for proteasomal degradation. However, under conditions of oxidative stress, Keap1 is oxidized, resulting in the release of Nrf2, which can then be translocated to the nucleus. It has been observed that Nrf2 activation in psoriasis leads to higher expression of keratins K6, K16, and K17, which enhance the proliferation of keratinocytes [58]. In Nrf2 ${ }^{-/}$mice, higher DNA oxidation and production of antibodies against DNA have been observed. Moreover, higher levels of cytokines and clinical symptoms similar to SLE have also been observed, which suggests that dysregulation of the Nrf2 system may be important in the development of SLE [59]. In addition, in a mouse model of pristane-induced lupus nephritis, administration of the Nrf2 activator dimethyl fumarate was found to cause alleviation of inflammation, providing additional evidence that Nrf2 activation has an anti-inflammatory role in autoimmune diseases similar to SLE [60]. Nrf2 also seems to be able to modulate cellular function in RA because the administration of S-propargyl-cysteine, which is a potent activator of the Nrf2 pathway, leads to alleviation of RA symptoms in a rat model and reduces the production of inflammatory cytokines in human rheumatoid fibroblast-like synoviocytes [61].

Oxidative-stress-induced modifications to transcription factors and intracellular signaling pathways may strongly affect functions of leukocytes, particularly dendritic cells. In vitro studies have shown that oxidative stress leads to activation of dendritic cells [62], the production of IL- 8 and TNF- $\alpha$ by these cells, and enhanced TLR expression, which may play an important role in their abnormal response to autoantigens [63]. It has been shown that in the presence of vitamins $C$ and $E$, the activation of dendritic cells is weaker and that 
lower amounts of cytokines, such as IL-1 $\beta$, IL-12, TNF- $\alpha$, and IFN- $\gamma$, are formed in vitro after administration of pro-inflammatory factors [64]. Moreover, lymphocytes co-cultured with dendritic cells previously treated with these vitamins are characterized by reduced proliferation and a shifted response toward Th2, i.e., production of IL-10, IL-4, and IL-5. In the presence of these antioxidant vitamins, the phosphorylation of the p38 mitogen activated protein kinase (MAPK) kinase also decreases, indicating inhibition of the p38 MAPK pathway [64]. This pathway is activated, among others, by UV, oxidative stress, and pro-inflammatory cytokines and leads to overproduction of TNF- $\alpha$ and IL-1, as well as apoptosis $[65,66]$. A decrease in ROS levels in dendritic cells was also confirmed after incubation with these antioxidant vitamins [64].

Vitamins are not the only antioxidants that have been studied for their effects on dendritic cells. Bursopentine is an antioxidant that has been shown to inhibit the production of nitric oxide (NO) in LPS-activated dendritic cells, which is accompanied by suppression of LPS activity, observed as a decrease in the production of TNF- $\alpha$ as well as inhibition of the maturation of these cells [67]. On the other hand, increasing ROS levels leads to increased activation of lymphocytes by dendritic cells [68]. These metabolic modifications are accompanied by the enhancement of lipid peroxidation in dendritic cells. Since activation of dendritic cells and interactions between dendritic cells and lymphocytes appear to be crucial for the development of autoimmune diseases, oxidative stress may be associated with the development of autoimmune diseases through action on dendritic cells [67]. Oxidative stress induces $\mathrm{T}$ lymphocyte polarization by enhancing their interaction with dendritic cells and may also directly increase Th17 development via the mammalian target of rapamycin (mTOR) pathway $[69,70]$. Antioxidants like resveratrol, which can inhibit the mTOR pathway, are known to have a positive effect in murine models of immunologic diseases [71]. In the case of B lymphocytes [72], their increased activation may be caused by increased activity of T lymphocytes, higher cytokine levels, or the direct influence of ROS. Oxidative stress caused by hydrogen peroxide has been shown to result in higher activation and maturation of $B$ lymphocytes and may accordingly also contribute to the development of diseases in which malfunction of B cells leads to the production of autoantibodies.

Taken together, these findings suggest that oxidative stress may be an important factor for the development of autoimmune diseases. It is well known that oxidative stress is caused by inflammation, but induced oxidative stress may also enhance inflammation. However, it is not certain whether oxidative stress is only a consequence, or it may also be the primary cause of inflammation in autoimmune diseases. Even if oxidative stress is a result of inflammation, it causes a further increase in the activity of leukocytes. Moreover, oxidative stress leads to significant changes in lipid metabolism, and lipid metabolites may also be involved in the pathophysiology of autoimmune diseases as shown by Figure 3 and Section 1.1.

In addition to some lipid mediators, ROS affect the pathophysiology of psoriasis by interacting with leukocytes at the very beginning of the inflammatory process. They may thus be triggers for the development of the disease, but they may also intensify the proliferation of keratinocytes, thereby intensifying symptoms of psoriasis. On the other hand, some lipid mediators, particularly endocannabinoids, seem to be anti-inflammatory factors.

ROS and lipid mediators play important roles in the onset of the pathological interactions between different leukocytes in SLE and RA. First, they are involved in regulating the activity of dendritic cells and the differentiation of lymphocytes. Afterward, they further activate other leukocytes, thereby enhancing inflammation. 


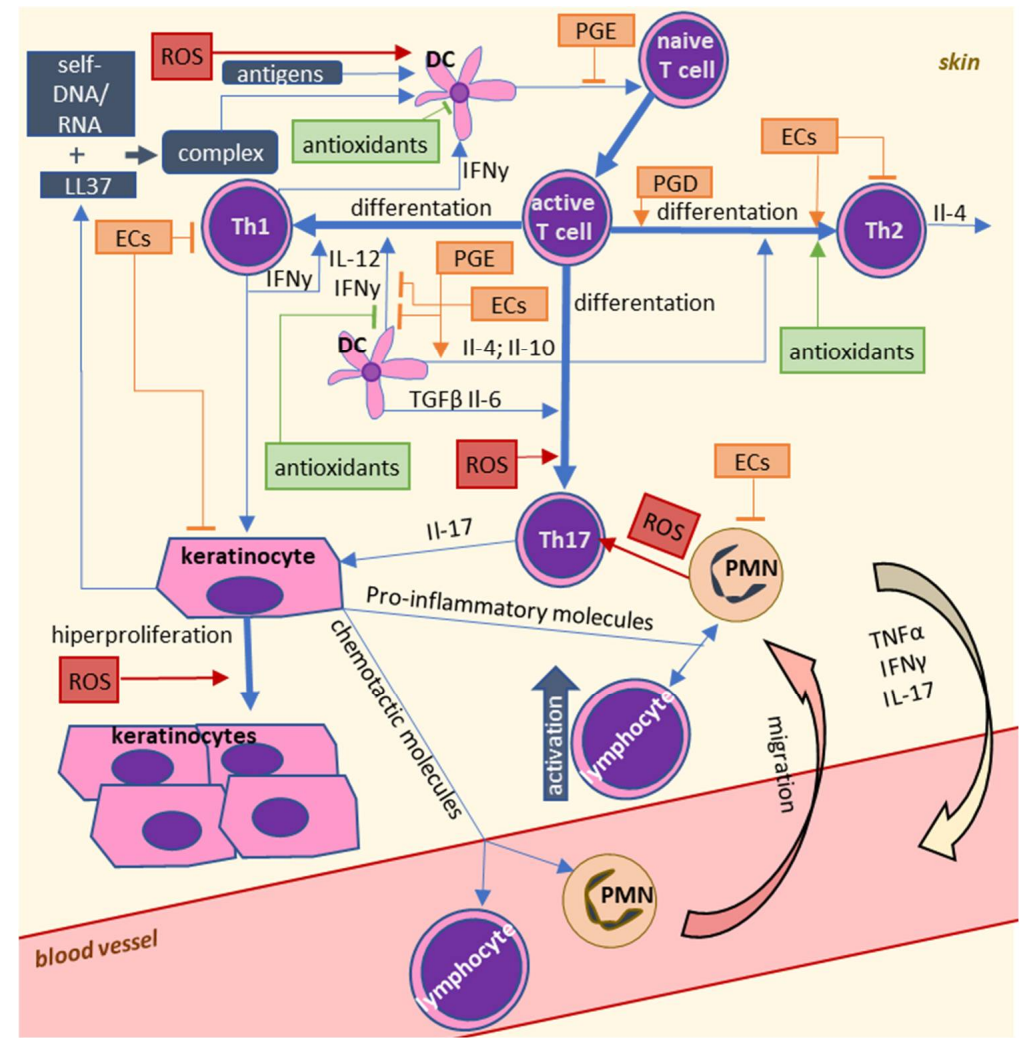

Figure 3. Influence of reactive oxygen species (ROS) and lipid mediators on immune cell interactions in psoriasis.

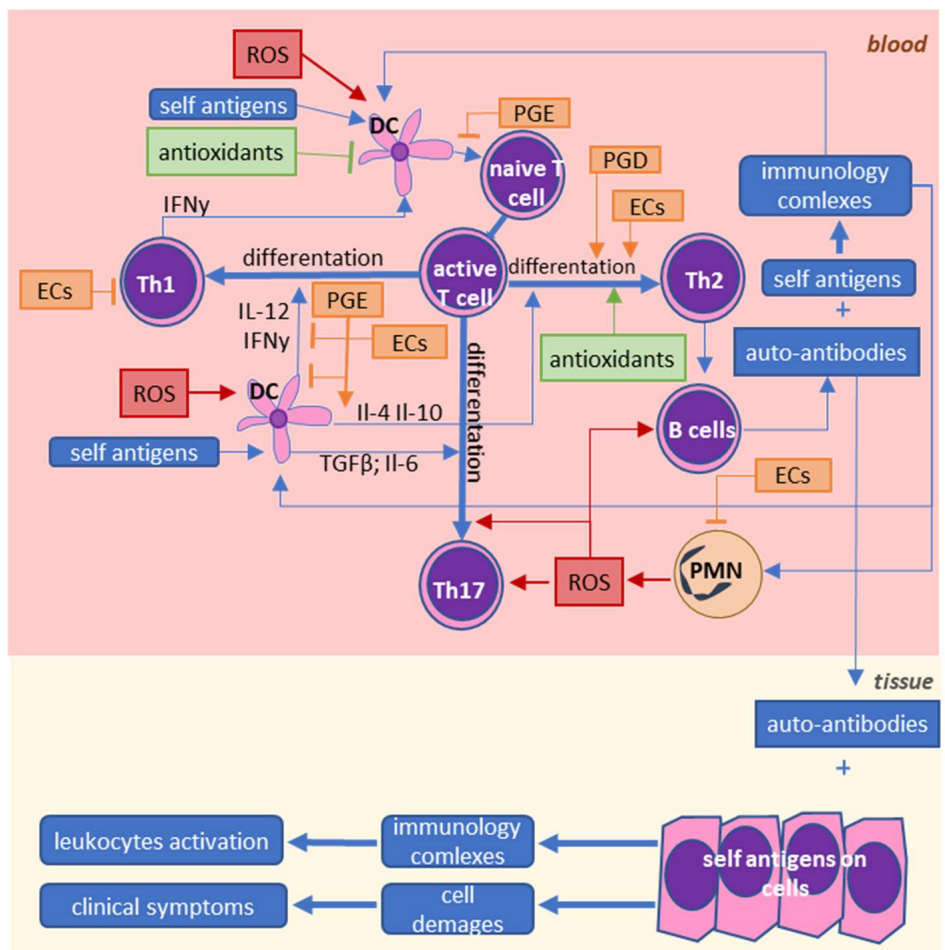

Figure 4. Influence of reactive oxygen species and lipid mediators on immune cell interactions in SLE and RA. 


\subsection{Lipid Mediators}

It is well known that oxidative stress promotes modification of lipid metabolism [34,73,74]. Oxidative conditions have been shown to promote the activation of enzymes such as phospholipase, cyclooxygenases (COX), lipoxygenases (LOX), and cytochrome p450 (CYP450) [75], which are involved in the metabolism of lipids and their derivatives, resulting in the formation of eicosanoids, which are, in turn, involved in modulation of the redox balance and inflammation by activating specific receptors. Phospholipids are also metabolized by N-acyltransferase (NAT), phospholipase C (PLC), diacylglycerol lipase (DAGL), and N-acylphosphatidylethanolamine phospholipase D (NAPE-PLD) into endocannabinoids (Figure 5) [76,77]. Moreover, oxidative conditions enhance ROS-dependent lipid metabolism, resulting in an increase of both oxidative fragmentation and oxidative cyclization of lipid hydrocarbon chains. The oxidative stress observed in autoimmune diseases leads to elevated levels of various lipid mediators. Genetic studies have confirmed that in at least some autoimmune diseases, lipid mediators are not only the result of oxidative stress and inflammation but also play an important role in modulating these processes [78].

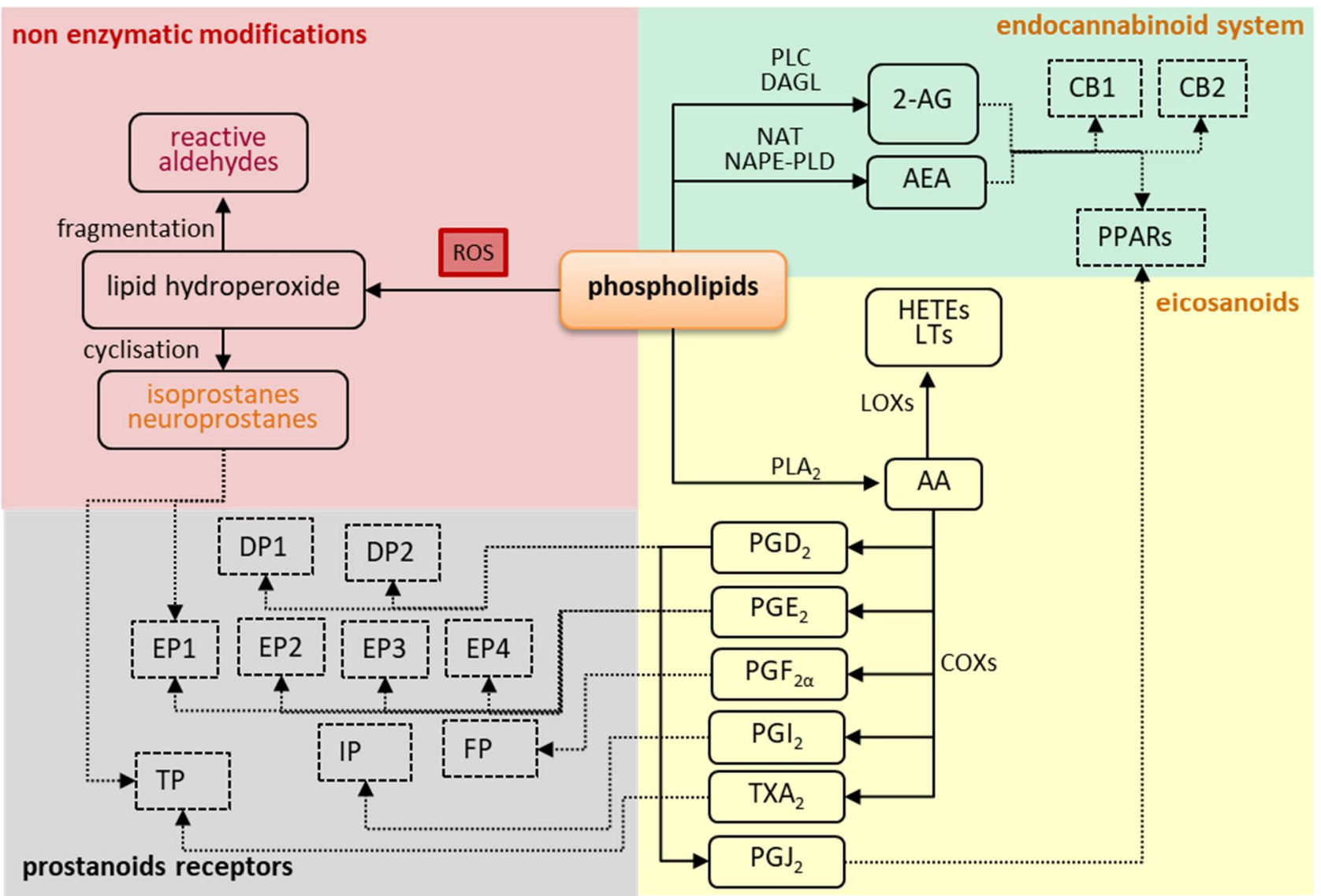

Figure 5. The most important lipid derivatives are generated from arachidonic acid in enzyme-dependent pathways and their receptors. Abnormal lipid metabolism is observed during oxidative stress. Non-enzymatic modifications involve the fragmentation and cyclization of lipids, leading to the formation of reactive aldehydes and isoprostanes, respectively. On the other hand, endocannabinoids and prostanoids are generated through the enzymatic pathway. These compounds affect cell functions by activating different receptors. Importantly, one compound may act on different receptors, while one receptor can be activated by different compounds.

\subsubsection{Endocannabinoids}

Endocannabinoids are a large group of ester, ether, and amide derivatives of fatty acids, of which the best-known mediators of cellular metabolism are anandamide (AEA) 
and 2-arachidonoyl glycerol (2-AG) [76,77]. Endocannabinoids are mainly biosynthesized from phospholipids present in the cell membrane. AEA synthesis begins when arachidonic acid is transferred from phosphatidylcholine to phosphatidylethanolamine, so thus-formed $\mathrm{N}$-arachidonoyl phosphatidylethanolamine is then hydrolyzed to AEA by phospholipase $\mathrm{A}_{2}$, C, or D [79]. However, the synthesis of 2-AG is catalyzed by diacylglycerol lipase, which hydrolyzes phosphatidylinositol [80]. Due to biological properties similar to endocannabinoids (activation of the same receptors), phytocannabinoids were discovered, of which cannabidiol and tetrahydrocannabinol are the best known for their effects on cellular metabolism [81-83].

Apart from other functions that include regulation of leukocyte metabolism, endocannabinoids fulfill their metabolic role in the body mainly through the activation of $G$ protein-coupled receptors. Among them, the most important are the cannabinoid receptors (CB1 and CB2), which have opposing effects relative to each other [76,77]. Activation of $\mathrm{CB} 1$ has pro-oxidative and pro-inflammatory effects, while $\mathrm{CB} 2$ activation enhances antioxidant and anti-inflammatory conditions $[76,77]$. Because CB2 is abundant in immune cells, endocannabinoids are considered to be the main regulators of inflammation, so the increased activation of cannabinoid receptors in autoimmune diseases is very often viewed as a protective mechanism [84]. This is supported by the fact that mutations in the CB2 receptor may lead to higher lymphocyte activity. Various mutations, including the nonsense mutations in enzymes that synthesize endocannabinoids, correlate with a higher risk of some autoimmune diseases [85,86]. Moreover, other receptors like peroxisomeproliferator-activated receptors (PPARs), especially PPAR- $\delta$ and PPAR- $\gamma$, are activated by endocannabinoids and act in an immunosuppressive manner [87].

On the other hand, phytocannabinoids, particularly cannabidiol (CBD), are able to inhibit neutrophil migration and ROS production, as CBD has been shown to cause a significant decrease of ROS levels in neutrophils in vitro [88]. The 2-AG also reduces neutrophil migration and degranulation, as well as ROS generation in the cells $[89,90]$. It may therefore be suggested that, by inhibiting the main mechanisms of action of neutrophils, cannabinoids can be important negative regulators of neutrophils and innate immunity.

Endocannabinoids also inhibit the synthesis of pro-inflammatory cytokines (e.g., IL-6, IL-12, and IFN $\gamma$ ) by dendritic cells that can thus impact the differentiation of lymphocytes to Th2 and prevent their differentiation to Th1 [91]. Endocannabinoids may also cause apoptosis of dendritic cells, thereby preventing the activation of lymphocytes and the development of adaptive immunity [92]. Moreover, it has been shown that endocannabinoids inhibit both activated Th1 and Th2 lymphocytes, so their addition to the cells in vitro decreases their production of cytokines (TNF- $\alpha$, IL-6, and IL-8, IFN $\gamma$ ) [91]. On the other hand, it is also suggested that endocannabinoids cause a shift of the lymphocytic profile to Th2 by inducing the production of IL-4 and IL-10 [93]. Therefore, endocannabinoids may be involved in T lymphocyte function, directly changing their phenotype and indirectly by modulating dendritic cell functions, thus changing the environment in which lymphocytes act and leading to lower cellular activation and changing their profile to Th2.

As with most autoimmune diseases, in psoriasis, SLE, and RA, the lymphocyte profile is shifted to Th1, and endocannabinoids may play an important role as negative regulators of autoimmune diseases. This may underpin certain compensatory mechanisms, especially in cases where endocannabinoid levels are elevated, as is the case in autoimmune diseases. In fact, in psoriasis vulgaris, levels of AEA and 2-AG, as well as expression of CB2 receptors, are enhanced in granulocytes and peripheral blood mononuclear cells (PBMC), while in psoriatic arthritis, expression of CB2 receptors is decreased in spite of elevation of endocannabinoids $[33,34]$. Therefore, exacerbation of psoriasis vulgaris to psoriatic arthritis may be caused by disturbances in the endocannabinoid system. However, in vitro studies have shown that CBD reduces inflammation and oxidative stress in keratinocytes in both healthy individuals and patients with psoriasis vulgaris, which may indicate beneficial properties of CBD [94]. Moreover, CBD also reduces the formation of a NETotic network in neutrophils [95]. However, topical application of CBD-containing oil decreases the 
Psoriasis Area and Severity Index (PASI) score in patients with psoriasis vulgaris [96]. However, in the case of SLE, plasma levels of 2-AG are also increased, which may result in decreased activity of lymphocytes. Similarly, higher levels of endocannabinoids have been observed in the synovial fluid of RA patients [97]. In addition, there is direct evidence that cannabinoids act in an immunosuppressive manner in RA $[98,99]$ and that CBD, similar to the synthetic selective CB2 agonist O3223, reduces the severity of symptoms in animal models of the disease $[98,99]$.

Therefore, the widely recognized anti-inflammatory effects of endocannabinoids appear to be well documented in autoimmune diseases. The action of these mediators alone will likely not be enough to reduce inflammation, since many other pro-inflammatory factors are also relevant for autoimmune diseases. Nevertheless, a positive response to cannabinoid-based treatment clearly indicates that the endocannabinoid system might dampen the activity of the immune system in autoimmune diseases [96,98].

\subsubsection{Eicosanoids}

Eicosanoids are another group of lipid mediators formed as a result of enzymatic metabolism of polyunsaturated fatty acids. The enzyme catalyzing the formation of eicosanoids is cyclooxygenase (COX-1 and COX-2). The COX-1 isoform is constitutively expressed, while COX-2 expression is highly dependent on the cellular environment [100]. However, inflammation or pro-inflammatory factors lead to overexpression of COX-1 [101].

The main substrate of cyclooxygenases is arachidonic acid (AA), which is released from phospholipids by phospholipase $\mathrm{A}_{2}$ [75]. Due to COX activity, AA is metabolized into twoseries eicosanoids, initially resulting in the formation of prostaglandin $\mathrm{G}_{2}\left(\mathrm{PGG}_{2}\right)$, which is subsequently reduced to $\mathrm{PGH}_{2}$, after which it is rapidly converted to other prostaglandins (e.g., $\mathrm{PGE}_{2}, \mathrm{PGF}_{2}, \mathrm{PGD}_{2}, \mathrm{PGI}_{2}$ ) and thromboxanes (e.g., thromboxane $\mathrm{A}_{2}$ ) via specific prostaglandin and thromboxane synthases [102]. Cyclooxygenases also metabolize other substrates such as endocannabinoids into AA, which may also be metabolized via the LOX and cytochrome P450 pathways with, e.g., hydroxyeicosatetraenoic acid (HETE) generation [102].

Prostaglandins are generally pro-inflammatory compounds, but their effect on immune cells is complex and is at least partially dependent on the activation of their receptors. Prostaglandins act through specific prostanoid receptors-namely prostanoid E receptors (EP1, EP2, EP3, and EP4) for $\mathrm{PGE}_{2}$; prostanoid D receptors (DP1 and DP2) for $\mathrm{PGD}_{2}$; prostanoid $\mathrm{F}$ receptors for $\mathrm{PGF}_{2 \alpha}$; prostanoid I receptor for $\mathrm{PGI}_{2}$ and the thromboxane receptor for TXA 2 [103-106]. Although no specific receptors for $\mathrm{PGJ}_{2}$ have been characterized so far, $P \mathrm{PJ}_{2}$ is an agonist of both the DP1 and DP2 receptors [103,107]. Prostaglandins may also activate PPAR receptors [107], and the diversity of receptors creates options for different cellular responses to prostaglandins, depending on the dominant activation of the receptor $[103,104]$.

Prostaglandins play important role in regulating the differentiation of lymphocytes into different cellular subpopulations. In the case of dendritic cells, the action of $\mathrm{PGE}_{2}$ limits the ability of these cells to activate naïve T lymphocytes. The $\mathrm{TXA}_{2}$ appears to suppress the interaction between dendritic and Th cells and thus reduces Th cell differentiation both in vitro and in vivo. Moreover, in the presence of $\mathrm{PGE}_{2}$, dendritic cells produce lower amounts of IL-12 and higher levels of IL-10, which leads to the differentiation of T cells into $\mathrm{Th}_{2}$ cells $[108,109]$. $\mathrm{PGD}_{2}$ also promotes the differentiation of $\mathrm{T}$ lymphocytes into $\mathrm{Th}_{2}$ cells and thus may indirectly promote $\mathrm{B}$ cell activation $[110,111]$. These data indicate the involvement of prostaglandins in the immune response and the generation of the Th2 phenotype. On the other hand, EP1 $1^{-/-}$mice show a diminished Th1 response, suggesting that $\mathrm{PGE}_{2}$ is also necessary for the development of a Th1 response [112]. Moreover, EP1 agonists in vitro promote Th1 responses [112], while $\mathrm{PGE}_{2}$ in vivo induces Th17 cell differentiation and the production of pro-inflammatory cytokines [113]. In contrast, aspirin, which is a COX-2 inhibitor, inhibits the development of Th1 and Th2 lymphocytes [114]. Moreover, in vitro COX-2 inhibition reduces B cell maturation and antibody production, 
for which EP2 and EP4 receptors are the most important as their agonists affect B cell activation $[115,116]$.

Both forms of psoriasis are characterized by increased activity of phospholipase $\mathrm{A}_{2}$ and COX-2 in lymphocytes, which favors increased levels of eicosanoids, particularly of the prostaglandin $\mathrm{PGE}_{2}$ [34]. The interactions of Th lymphocytes, their activities, and the balance between their subpopulations appear to be crucial in psoriasis [5]. It should be said that the differentiation of Th17 lymphocytes seems to be dependent on the action of prostaglandins, and studies in mice show that the EP2 and EP4 receptors are necessary for the differentiation of Th17 cells in psoriasis [114]. In addition, deletion of EP2 or EP4 in mice leads to a reduction of both inflammation and symptoms of psoriasis [114]. HETEs may also play a role in psoriasis development because their elevated levels, as well as higher expression of main enzymes responsible for HETEs generation, such as 12(R)-LOX [117,118], are observed in the affected skin. In the skin, HETEs may act as a chemoattractant for neutrophils and lymphocytes, leading to their accumulation $[118,119]$. Besides the skin, higher HETEs levels are observed in psoriatic peripheral blood lymphocytes [34]. In the case of these cells, HETEs cause a shift of Th into Th1 lymphocytes and decrease Th2 cytokines synthesis, so they enhance the differentiation of lymphocytes. Because the differentiation of lymphocytes into Th1 is linked with psoriasis in this way, HETEs may increase disease severity [120].

On the other hand, it is known that another group of lipid mediators formed in reactions catalyzed by LOXs and leukotrienes (LT) are able to regulate immune cells, but in allergic and not in autoimmune diseases [121].

As in psoriasis, there is also an increase in the activity of phospholipase $\mathrm{A}_{2}$ and COX-2 occurring in RA and SLE [122,123]. Consequently, in RA, higher levels of prostaglandins, especially $\mathrm{PGD}_{2}$ and $\mathrm{PGE}_{2}$, are observed in the synovial fluid, while in SLE, levels of $\mathrm{PGD}_{2}$ in the plasma are increased [124]. Nevertheless, the role of these prostaglandins is better known for RA. Namely, $\mathrm{PGD}_{2}$ is one of the factors responsible for enhanced proliferation and decreased apoptosis of chondrocytes [125]. On the other hand, $\mathrm{PGE}_{2}$ seems to be one of the most important pro-inflammatory factors in RA, and interactions between $\mathrm{PGE}_{2}$ and its receptors may be a key element in the pathogenesis of the disease. Studies in rats have shown that administration of an EP4 selective antagonist leads to inflammation and symptoms of RA [126]. Since antagonists of other EP receptors (EP1-EP3) do not influence the severity of RA, it seems that EP4 is the crucial one [126]. Moreover, deletion of the EP2 or EP4 receptors results in a reduction in disease severity in a mouse model of RA. This may further suggest that EP4 plays a key role in the pathophysiology of RA [78], and antagonists that inhibit signaling of the receptor lead to a reduction in inflammation [126]. In contrast, even residual EP2 signaling is sufficient to lead to the development of inflammation, since antagonists are unable to completely block signaling compared to genetic deletion of the receptor $[78,126]$.

However, both prostaglandins and HETEs are involved in the pathophysiology of rheumatoid arthritis. Studies on genetically modified mice have shown that the elimination of 15-LOX, which impairs the synthesis of 15-HETE, leads to the alleviation of the symptoms of the disease. Conversely, administration of 15-HETE leads to a higher generation of TNF$\alpha$ and IL-1 in the same model [127]. In humans, 15-LOX is also present in the synovial tissue of rheumatoid arthritis patients [128], suggesting that the 15-HETE generation plays a role in the pathophysiology of RA and that the results of studies in mice may be applicable to human.

\subsubsection{Non-Enzymatic Modifications}

Another group of lipid mediators formed in ROS-dependent reactions consists of lipid peroxidation products. Depending on the mechanism of formation, these can be divided into reactive, electrophilic $\alpha$, and $\beta$-unsaturated aldehydes, which are products of oxidative fragmentation and interact with compounds having nucleophilic centers such as lipids and proteins, or prostaglandin derivatives with lower chemical reactivity resulting 
from oxidative cyclization of phospholipid unsaturated fatty acids [129-131]. Aldehydes, mainly 4-hydroxynonenal (4-HNE) and malondialdehyde (MDA), can act as antigens for immune cells, leading to the production of antibodies [132]. It is known that 4-HNE enhances activation of TLR4, which may lead to activation of dendritic cells and therefore lymphocytes and other leukocytes [133]. Moreover, 4-HNE activates NF- $k B$, so it may therefore act as an activator of immune cells $[134,135]$. Since NF- $k B$ is one of the most important transcription factors that regulate the production of pro-inflammatory cytokines, its activation leads to the onset of inflammation.

Increased levels of 4-HNE and 4-HNE protein adducts have been observed in plasma and blood cells, as well as skin cells (keratinocytes and fibroblasts) of patients with psoriasis [33,136-138], causing higher expression of NF-kB and TNF $\alpha$ in blood cells [33]. This suggests that 4-HNE may be involved in NF- $\kappa B$ activation and inflammation in psoriasis. Similarly, higher levels of 4-HNE and 4-HNE protein adducts have been observed in RA and SLE [139-141]. Since reactive aldehydes and other lipid derivatives can act as autoantigens, antibodies to MDA and MDA-LDL adducts have been observed in the blood of patients with SLE [132]. However, antibodies to enzymatic lipid metabolism products, such as 9-HODE and 13-HODE, have also been observed in SLE, and their levels correlated with disease severity [132], while antibodies to MDA have also been observed in RA [142]. However, it is not known whether this increase in anti-lipid antibodies is significant for the development of SLE or RA, or whether it is merely a result of increased oxidative stress manifested by higher levels of oxidized molecules. Since immune complexes consisting of an antibody and its target are known to be powerful activators of the immune system, they are likely to be involved in the development or at least exacerbation of SLE. In psoriasis, autoantibodies to lipid derivatives have not yet been reported, although an increase in levels of these derivatives is observed [33]. Aldehydes form as a result of ROS-dependent fragmentation of polyunsaturated fatty acids and act as oxidative compounds that intensify oxidative stress. On the other hand, these molecules, particularly 4-HNE, are important pro-apoptotic agents that can enhance the pro-apoptotic pathways of immune cells and thus suppress inflammation [49].

Lipid cyclization products may also be involved in inflammatory reactions, and at least some of the effects of isoprostanes are due to their chemical similarity with prostaglandins; hence, isoprostanes may also act through prostaglandin receptors [129]. It has been shown that 8-isoPGE 2 and 8-isoPGF $2 \alpha$ enhance the interactions between endothelial cells, macrophages, and neutrophils and thus increase migration of these cells to the site of inflammation $[143,144]$. Moreover, 8 -isoPGF $2 \alpha$ can activate the MAPK pathway in macrophages causing higher production of IL-8 in the cells [145]. Because IL-8 is important in the differentiation of lymphocytes into Th1 cells, 8 -isoPGF ${ }_{2 \alpha}$ may enhance inflammation in autoimmune diseases [91]. In contrast, isoprostanes can also act as anti-inflammatory agents by reacting with cysteine residues in IкB kinase (IKK). Typically, IKK phosphorylates NF- $k B$ inhibitors, leading to their conjugation with ubiquitin and subsequent degradation and resulting in activation of NF- $\mathrm{KB}$ [146]. However, since 15-A2-isoprostanes interfere with this process, they lead to lower activation of NF-KB [146]. Higher levels of isoprostanes have been observed in most autoimmune diseases including psoriasis, SLE, RA, and in other conditions that are accompanied by oxidative stress $[33,140,141]$. Even though isoprostanes may play a role in modulation of immune cell function, they are so far mostly considered to be markers of oxidative stress, with their impact believed to be less important than the impact of other lipid derivatives in the case of immunity.

This situation again shows two faces of ROS and induced by them the oxidative stress and its effects, in this case an increase in the level of isoprostanes. A similar response was generated by the effects of dimethylformamide (DMF)pharmacotherapy for multiple sclerosis [147], manifested by an increase in ROS production, which was considered to control the dysregulated autoimmune response of monocytes. Presumably, a similar situation applies to other autoimmune diseases, such as those that are the focus of this review. 


\section{Conclusions}

It can be assumed that oxidative stress that accompanies autoimmune diseases may intensify inflammation. In addition, there is ample evidence that reactive oxygen species (ROS) increases inflammation and activates immune cells. The products of ROS-dependent lipid metabolism are also generally considered as pro-inflammatory agents and are observed at higher levels in autoimmune diseases. The situation is more complicated for enzymatic lipid metabolism products as some of these may act as pro-inflammatory factors, while others as anti-inflammatory ones [112]. Furthermore, it appears that endocannabinoids can act in two directions depending on which receptor they activate; however, because CB2 receptors predominate in immune cells and most studies show that endocannabinoids reduce immune cell activity, increased endocannabinoid production in autoimmune diseases is usually considered as a compensatory mechanism that at least partially reduces inflammation. Perhaps the most perplexing situation is with eicosanoids, which are in part anti-inflammatory factors and increase differentiation of lymphocytes to Th2, while they are probably necessary for the development of both Th1 and Th2 responses. Despite this, complex interactions between lipids and the immune system are intensified during autoimmune diseases and, together with oxidative stress, act as important factors of their pathogenesis, which is still not entirely understood.

Author Contributions: Conceptualization, E.S.; resources, P.W.; writing—original draft preparation, P.W., A.G.; writing—review and editing, A.G., E.S.; visualization, P.W.; supervision, N.Ž.; funding acquisition, E.S. All authors have read and agreed to the published version of the manuscript.

Funding: This study was financed by the National Science Centre Poland (NCN) grant no. 2016/23 /B/NZ7/02350 Cooperation between coauthors is financed by the Polish National Agency for Academic Exchange (NAWA) as part of the International Academic Partnerships (PPI/APM/ 2018/00015/U/001).

Institutional Review Board Statement: Not applicable.

Informed Consent Statement: Not applicable.

Data Availability Statement: Data sharing not applicable.

Conflicts of Interest: The authors declare no conflict of interest.

$\begin{array}{ll}\text { Abbreviations } \\ \text { 2-AG } & \text { 2-Arachidonylglycerol } \\ \text { 4-HNE } & \text { 4-Hydroxynonenal } \\ \text { 4-ONE } & \text { 4-Oxynonenal } \\ \text { AEA } & \text { Anandamide } \\ \text { CB } & \text { Cannabinoid receptor } \\ \text { COX } & \text { Cyclooxygenase } \\ \text { DAGL } & \text { Diacylglycerol lipase } \\ \text { DP } & \text { Prostaglandin D receptor } \\ \text { EP } & \text { Prostaglandin E receptor } \\ \text { IFN } \gamma & \text { Interferon } \gamma \\ \text { IL } & \text { Interleukin } \\ \text { IMQ } & \text { Imiquimod } \\ \text { IPP } & \text { Prostaglandin I receptor } \\ \text { LOX } & \text { Lipoxygenases } \\ \text { LTB4 } & \text { Leukotriene B4 } \\ \text { MDA } & \text { Malondialdehyde } \\ \text { NAPE-PLD } & \text { N-acylphosphatidylethanolamine phospholipase D } \\ \text { NAT } & \text { N-acyltransferase } \\ \text { NFKB } & \text { Nuclear factor kappa-light-chain-enhancer of activated B cells }\end{array}$




$\begin{array}{ll}\text { Nrf2 } & \text { Nuclear factor erythroid 2-like } \\ \text { OEA } & \text { Oleoylethanolamide } \\ \text { PGE } & \text { Prostaglandin D } \\ \text { PGE } & \text { Prostaglandin E } \\ \text { PGF } & \text { Prostaglandin F } \\ \text { PGI } & \text { Prostaglandin I } \\ \text { PGJ } & \text { Prostaglandin J } \\ \text { PLA } 2 & \text { Phospholipase A2 } \\ \text { PLC } & \text { Phospholipase C } \\ \text { PUFAs } & \text { Polyunsaturated fatty acids } \\ \text { RA } & \text { Rheumatic arthritis } \\ \text { ROS } & \text { Reactive oxygen species } \\ \text { SLE } & \text { Systemic lupus erythematosus } \\ \text { Th } & \text { Thelper lymphocytes } \\ \text { TLR } & \text { Toll like receptor } \\ \text { TNF } \alpha & \text { Tumor necrosis factor } \alpha \\ \text { TNFR } & \text { Tumor necrosis factor receptor } \\ \text { TRPV1 } & \text { The transient receptor potential cation channel subfamily V member } 1 \\ \text { TXA } 2 & \text { Thromboxane A2 }\end{array}$

\section{References}

1. Fortina, A.B.; Bardazzi, F.; Berti, S.; Carnevale, C.; Di Lernia, V.; El Hachem, M.; Neri, I.; Gelmetti, C.M.; Lora, V.; Mazzatenta, C.; et al. Treatment of severe psoriasis in children: Recommendations of an Italian expert group. Eur. J. Pediatr. 2017, 176, 1339-1354. [CrossRef] [PubMed]

2. Jesus, D.; Matos, A.; Henriques, C.; Zen, M.; LaRosa, M.; Iaccarino, L.; Da Silva, J.A.P.; Doria, A.; Inês, L.S. Derivation and validation of the SLE Disease Activity Score (SLE-DAS): A new SLE continuous measure with high sensitivity for changes in disease activity. Ann. Rheum. Dis. 2019, 78, 365-371. [CrossRef] [PubMed]

3. Gonçalves, R.S.G.; Pereira, G.A.; de Andrade Lima, E.; Martins, T.H.F.; Junior, J.O.A.; Carvalho, J.B.; Mariz, H.A.; Dantas, A.T.; Duarte, A.L.B.P. Validation of the Toronto Psoriatic Arthritis Screen II (ToPAS II) questionnaire in a Brazilian population. Clin. Rheumatol. 2020. [CrossRef] [PubMed]

4. Farid, E.; Mumtaz, M.; Hajji, F.; Ebrahim, R.A.; Abdulla, H.; Tabbara, K. T Regulatory Cells in Rheumatoid Arthritis with Reference to Anti-Citrullinated Peptide Antibody and TNF-alpha Inhibitor Therapy. Egypt J. Immunol. 2020, 27, 55-63. [PubMed]

5. Dogra, S.; Mahajan, R. Psoriasis: Epidemiology, clinical features, co-morbidities, and clinical scoring. Indian Dermatol. Online J. 2016, 7, 471-480. [CrossRef]

6. Capon, F. The Genetic Basis of Psoriasis. Int. J. Mol. Sci. 2017, 18, 2526. [CrossRef] [PubMed]

7. Wasserman, A. Diagnosis and management of rheumatoid arthritis. Am. Fam. Physician 2011, 84, 1245-1252.

8. Fava, A.; Petri, M. Systemic lupus erythematosus: Diagnosis and clinical management. J. Autoimmun. 2019, 96, 1-13. [CrossRef]

9. Patente, T.A.; Pinho, M.P.; Oliveira, A.A.; Evangelista, G.C.M.; Bergami-Santos, P.C.; Barbuto, J.A.M. Human Dendritic Cells: Their Heterogeneity and Clinical Application Potential in Cancer Immunotherapy. Front. Immunol. 2019, 9, 3176. [CrossRef]

10. Li, J.-G.; Du, Y.-M.; Yan, Z.-D.; Yan, J.; Zhuansun, Y.-X.; Chen, R.; Zhang, W.; Feng, S.-L.; Ran, P.-X. CD80 and CD86 knockdown in dendritic cells regulates Th1/Th2 cytokine production in asthmatic mice. Exp. Ther. Med. 2016, 11, 878-884. [CrossRef]

11. Gilliet, M.; Lande, R. Antimicrobial peptides and self-DNA in autoimmune skin inflammation. Curr. Opin. Immunol. 2008, 20, 401-407. [CrossRef]

12. Ueki, M.; Kimura-Kataoka, K.; Fujihara, J.; Iida, R.; Kawai, Y.; Kusaka, A.; Sasaki, T.; Takeshita, H.; Yasuda, T. Evaluation of the functional effects of genetic variants-missense and nonsense SNPs, indels and copy number variations-in the gene encoding human deoxyribonuclease I potentially implicated in autoimmunity. Sci. Rep. 2019, 9, 13660. [CrossRef] [PubMed]

13. Lund, J.M.; Alexopoulou, L.; Sato, A.; Karow, M.; Adams, N.C.; Gale, N.W.; Iwasaki, A.; Flavell, R.A. Recognition of singlestranded RNA viruses by Toll-like receptor 7. Proc. Natl. Acad. Sci. USA 2004, 101, 5598-5603. [CrossRef] [PubMed]

14. Wang, T.; Marken, J.; Chen, J.; Tran, V.B.; Li, Q.-Z.; Li, M.; Cerosaletti, K.; Elkon, K.B.; Zeng, X.; Giltiay, N.V. High TLR7 Expression Drives the Expansion of CD19+CD24hiCD38hi Transitional B Cells and Autoantibody Production in SLE Patients. Front. Immunol. 2019, 10, 1243. [CrossRef] [PubMed]

15. García-Ortiz, H.; Velázquez-Cruz, R.; Espinosa-Rosales, F.; Jiménez-Morales, S.; Baca, V.; Orozco, L. Association of TLR7 copy number variation with susceptibility to childhood-onset systemic lupus erythematosus in Mexican population. Ann. Rheum. Dis. 2010, 69, 1861-1865. [CrossRef] [PubMed]

16. Lai, C.-Y.; Su, Y.-W.; Lin, K.-I.; Hsu, L.-C.; Chuang, T.-H. Natural Modulators of Endosomal Toll-Like Receptor-Mediated Psoriatic Skin Inflammation. J. Immunol. Res. 2017, 2017, 1-15. [CrossRef]

17. Huang, Q.-Q.; Pope, R.M. The role of Toll-like receptors in rheumatoid arthritis. Curr. Rheumatol. Rep. 2009, 11, 357-364. [CrossRef] 
18. Chamberlain, N.D.; Kim, S.; Vila, O.M.; Volin, M.V.; Volkov, S.; Pope, R.M.; Arami, S.; Mandelln, A.M.; Shahrara, S. Ligation of TLR7 by rheumatoid arthritis synovial fluid single strand RNA induces transcription of TNF $\alpha$ in monocytes. Ann. Rheum. Dis. 2013, 72, 418-426. [CrossRef]

19. Nie, F.; Ding, F.; Chen, B.; Huang, S.; Liu, Q.; Xu, C. Dendritic cells aggregate inflammation in experimental osteoarthritis through a toll-like receptor (TLR)-dependent machinery response to challenges. Life Sci. 2019, 238, 116920. [CrossRef]

20. Bengtsson, A.A.; Sturfelt, G.; Truedsson, L.; Blomberg, J.; Alm, G.; Vallin, H.; Rönnblom, L. Activation of type I interferon system in systemic lupus erythematosus correlates with disease activity but not with antiretroviral antibodies. Lupus 2000, 9, 664-671. [CrossRef]

21. Ohl, K.; Tenbrock, K. Inflammatory Cytokines in Systemic Lupus Erythematosus. J. Biomed. Biotechnol. 2011, 2011, 1-14. [CrossRef]

22. Prajeeth, C.K.; Kronisch, J.; Khorooshi, R.; Knier, B.; Toft-Hansen, H.; Gudi, V.; Floess, S.; Huehn, J.; Owens, T.; Korn, T.; et al. Effectors of Th1 and Th17 cells act on astrocytes and augment their neuroinflammatory properties. J. Neuroinflamm. 2017, 14, 1-14. [CrossRef]

23. Prinz, J.C.; Gross, B.; Vollmer, S.; Trommler, P.; Strobel, I.; Meurer, M.; Plewig, G. T cell clones from psoriasis skin lesions can promote keratinocyte proliferation in vitro via secreted products. Eur. J. Immunol. 1994, 24, 593-598. [CrossRef] [PubMed]

24. Hoffman, W.; Lakkis, F.G.; Chalasani, G. B Cells, Antibodies, and More. Clin. J. Am. Soc. Nephrol. 2016, 11, 137-154. [CrossRef]

25. Dema, B.; Charles, N. Autoantibodies in SLE: Specificities, Isotypes and Receptors. Antibodies 2016, 5, 2. [CrossRef]

26. Tiwari, V.; Jandu, J.S.; Bergman, M.J. Rheumatoid Factor. In StatPearls; StatPearls Publishing: Treasure Island, FL, USA, 2020.

27. Singh, S.; Singh, U.; Singh, S. Prevalence of autoantibodies in patients of psoriasis. J. Clin. Lab. Anal. 2010, 24, 44-48. [CrossRef]

28. Mishra, A.; Guo, Y.; Zhang, L.; More, S.; Weng, T.; Chintagari, N.R.; Huang, C.; Liang, Y.; Pushparaj, S.; Gou, D.; et al. A Critical Role for P2X7 Receptor-Induced VCAM-1 Shedding and Neutrophil Infiltration during Acute Lung Injury. J. Immunol. 2016, 197, 2828-2837. [CrossRef]

29. Feng, D.; Nagy, J.A.; Pyne, K.; Dvorak, H.F.; Dvorak, A.M. Neutrophils Emigrate from Venules by a Transendothelial Cell Pathway in Response to FMLP. J. Exp. Med. 1998, 187, 903-915. [CrossRef]

30. Wang, X.; Qin, W.; Zhang, Y.; Zhang, H.; Sun, B. Endotoxin promotes neutrophil hierarchical chemotaxis via the p38-membrane receptor pathway. Oncotarget 2016, 7, 74247-74258. [CrossRef]

31. Tang, D.; Kang, R.; Coyne, C.B.; Zeh, H.J.; Lotze, M.T. PAMPs and DAMPs: Signal 0s that spur autophagy and immunity. Immunol. Rev. 2012, 249, 158-175. [CrossRef]

32. Brinkmann, V.; Zychlinsky, A. Neutrophil extracellular traps: Is immunity the second function of chromatin? J. Cell Biol. 2012, 198, 773-783. [CrossRef]

33. Ambrożewicz, E.; Wójcik, P.; Wroński, A.; Łuczaj, W.; Jastrząb, A.; Žarković, N.; Skrzydlewska, E. Pathophysiological Alterations of Redox Signaling and Endocannabinoid System in Granulocytes and Plasma of Psoriatic Patients. Cells 2018, 7, 159. [CrossRef]

34. Wójcik, P.; Biernacki, M.; Wroński, A.; Łuczaj, W.; Waeg, G.; Žarković, N.; Skrzydlewska, E. Altered Lipid Metabolism in Blood Mononuclear Cells of Psoriatic Patients Indicates Differential Changes in Psoriasis Vulgaris and Psoriatic Arthritis. Int. J. Mol. Sci. 2019, 20, 4249. [CrossRef] [PubMed]

35. Asefi, M.; Vaisi-Raygani, A.; Bahrehmand, F.; Kiani, A.; Rahimi, Z.; Nomani, H.; Ebrahimi, A.; Tavilani, H.; Pourmotabbed, T. Paraoxonase 1 (PON1) 55 polymorphism, lipid profiles and psoriasis. Br. J. Dermatol. 2012, 167, 1279-1286. [CrossRef] [PubMed]

36. Peluso, I.; Cavaliere, A.; Palmery, M. Plasma total antioxidant capacity and peroxidation biomarkers in psoriasis. J. Biomed. Sci. 2016, 23, 52. [CrossRef]

37. Wang, W.; Yuhai; Wang, H.; Chasuna; Bagenna. Astilbin reduces ROS accumulation and VEGF expression through Nrf2 in psoriasis-like skin disease. Biol. Res. 2019, 52, 1-8. [CrossRef] [PubMed]

38. Lightfoot, Y.L.; Blanco, L.P.; Kaplan, M.J. Metabolic abnormalities and oxidative stress in lupus. Curr. Opin. Rheumatol. 2017, 29, 442-449. [CrossRef]

39. García-González, A.; Gaxiola-Robles, R.; Zenteno-Savín, T. Oxidative stress in patients with rheumatoid arthritis. Rev. Investig. Clin. 2015, 67, 46-53.

40. Zhang, H.; Fu, R.; Guo, C.; Huang, Y.; Wang, H.; Wang, S.; Zhao, J.; Yang, N. Anti-dsDNA antibodies bind to TLR4 and activate NLRP3 inflammasome in lupus monocytes/macrophages. J. Transl. Med. 2016, 14, 1-12. [CrossRef]

41. Wang, H.; Li, T.; Chen, S.; Gu, Y.; Ye, S. Neutrophil Extracellular Trap Mitochondrial DNA and Its Autoantibody in Systemic Lupus Erythematosus and a Proof-of-Concept Trial of Metformin. Arthritis Rheumatol. 2015, 67, 3190-3200. [CrossRef]

42. Lai, Z.-W.; Hanczko, R.; Bonilla, E.; Caza, T.N.; Clair, B.; Bartos, A.; Miklossy, G.; Jimah, J.; Doherty, E.; Tily, H.; et al. Nacetylcysteine reduces disease activity by blocking mammalian target of rapamycin in T cells from systemic lupus erythematosus patients: A randomized, double-blind, placebo-controlled trial. Arthritis Rheum. 2012, 64, 2937-2946. [CrossRef] [PubMed]

43. Ishikawa, Y.; Terao, C. The Impact of Cigarette Smoking on Risk of Rheumatoid Arthritis: A Narrative Review. Cells 2020, 9, 475. [CrossRef]

44. Costenbader, K.H.; Feskanich, D.; Mandl, L.A.; Karlson, E.W. Smoking Intensity, Duration, and Cessation, and the Risk of Rheumatoid Arthritis in Women. Am. J. Med. 2006, 119, 503.e1-503.e9. [CrossRef] [PubMed]

45. Di Giuseppe, D.; Discacciati, A.; Orsini, N.; Wolk, A. Cigarette smoking and risk of rheumatoid arthritis: A dose-response meta-analysis. Arthritis Res. Ther. 2014, 16, R61. [CrossRef] [PubMed]

46. Datta, S.; Kundu, S.; Ghosh, P.; De, S.; Ghosh, A.; Chatterjee, M. Correlation of oxidant status with oxidative tissue damage in patients with rheumatoid arthritis. Clin. Rheumatol. 2014, 33, 1557-1564. [CrossRef] 
47. Toukap, A.N.; Delporte, C.; Noyon, C.; Franck, T.; Rousseau, A.; Serteyn, D.; Raes, M.; Vanhaeverbeek, M.; Moguilevsky, N.; Nève, J.; et al. Myeloperoxidase and its products in synovial fluid of patients with treated or untreated rheumatoid arthritis. Free Radic. Res. 2014, 48, 461-465. [CrossRef]

48. Jaganjac, M.; Cipak, A.; Schaur, R.J.; Zarkovic, N. Pathophysiology of neutrophil-mediated extracellular redox reactions. Front. Biosci. 2016, 21, 839-855. [CrossRef]

49. Wójcik, P.; Žarković, N.; Gęgotek, A.; Skrzydlewska, E. Involvement of Metabolic Lipid Mediators in the Regulation of Apoptosis. Biomolecules 2020, 10, 402. [CrossRef]

50. Sokolova, O.; Naumann, M. NF-кB Signaling in Gastric Cancer. Toxins 2017, 9, 119. [CrossRef]

51. Miraghazadeh, B.; Cook, M.C. Nuclear Factor-kappaB in Autoimmunity: Man and Mouse. Front. Immunol. 2018, 9, 613. [CrossRef]

52. Farrugia, M.; Baron, B. The role of TNF- $\alpha$ in rheumatoid arthritis: A focus on regulatory T cells. J. Clin. Transl. Res. 2016, 2, 84-90. [CrossRef] [PubMed]

53. Perdriger, A. Infliximab in the treatment of rheumatoid arthritis. Biologics 2009, 3, 183-191. [CrossRef] [PubMed]

54. Navarro-Sarabia, F.; Ariza-Ariza, R.; Hernández-Cruz, B.; Villanueva, I. Adalimumab for treating rheumatoid arthritis. J. Rheumatol. 2006, 33, 1075-1081. [CrossRef] [PubMed]

55. Zhao, S.; Mysler, E.; Moots, R.J. Etanercept for the treatment of rheumatoid arthritis. Immunotherapy 2018, 10, 433-445. [CrossRef]

56. Nguyen, T.U.; Koo, J. Etanercept in the treatment of plaque psoriasis. Clin. Cosmet. Investig. Dermatol. 2009, 2, 77-84. [CrossRef]

57. Buendia, I.; Michalska, P.; Navarro, E.; Gameiro, I.; Egea, J.; León, R. Nrf2-ARE pathway: An emerging target against oxidative stress and neuroinflammation in neurodegenerative diseases. Pharmacol. Ther. 2016, 157, 84-104. [CrossRef]

58. Yang, L.; Fan, X.; Cui, T.; Dang, E.; Wang, G. Nrf2 Promotes Keratinocyte Proliferation in Psoriasis through Up-Regulation of Keratin 6, Keratin 16, and Keratin 17. J. Investig. Dermatol. 2017, 137, 2168-2176. [CrossRef]

59. Li, J.; Stein, T.D.; Johnson, J.A. Genetic dissection of systemic autoimmune disease in Nrf2-deficient mice. Physiol. Genom. 2004, 18, 261-272. [CrossRef]

60. Ebihara, S.; Tajima, H.; Ono, M. Nuclear factor erythroid 2-related factor 2 is a critical target for the treatment of glucocorticoidresistant lupus nephritis. Arthritis Res. Ther. 2016, 18, 1-12. [CrossRef]

61. Ferrándiz, M.L.; Nacher-Juan, J.; Alcaraz, M.J. Nrf2 as a therapeutic target for rheumatic diseases. Biochem. Pharmacol. 2018, 152, 338-346. [CrossRef]

62. Pazmandi, K.; Magyarics, Z.; Boldogh, I.; Csillag, A.; Rajnavolgyi, E.; Bacsi, A. Modulatory effects of low-dose hydrogen peroxide on the function of human plasmacytoid dendritic cells. Free Radic. Biol. Med. 2012, 52, 635-645. [CrossRef]

63. Akhter, N.; Madhoun, A.; Arefanian, H.; Wilson, A.; Kochumon, S.; Thomas, R.; Shenouda, S.; Al-Mulla, F.; Ahmad, R.; Sindhu, S. Oxidative Stress Induces Expression of the Toll-Like Receptors (TLRs) 2 and 4 in the Human Peripheral Blood Mononuclear Cells: Implications for Metabolic Inflammation. Cell Physiol. Biochem. 2019, 53, 1-18.

64. Tan, P.H.; Sagoo, P.; Chan, C.; Yates, J.B.; Campbell, J.; Beutelspacher, S.C.; Foxwell, B.M.J.; Lombardi, G.; George, A.J.T. Inhibition of NF- $\mathrm{kB}$ and Oxidative Pathways in Human Dendritic Cells by Antioxidative Vitamins Generates Regulatory T Cells. J. Immunol. Res. 2005, 174, 7633-7644. [CrossRef] [PubMed]

65. Koga, Y.; Tsurumaki, H.; Aoki-Saito, H.; Sato, M.; Yatomi, M.; Takehara, K.; Hisada, T. Roles of Cyclic AMP Response Element Binding Activation in the ERK1/2 and p38 MAPK Signalling Pathway in Central Nervous System, Cardiovascular System, Osteoclast Differentiation and Mucin and Cytokine Production. Int. J. Mol. Sci. 2019, 20, 1346. [CrossRef] [PubMed]

66. Cuadrado, A.; Nebreda, A.R. Mechanisms and functions of p38 MAPK signalling. Biochem. J. 2010, 429, 403-417. [CrossRef]

67. Qin, T.; Yin, Y.; Yu, Q.; Yang, Q. Bursopentin (BP5) Protects Dendritic Cells from Lipopolysaccharide-Induced Oxidative Stress for Immunosuppression. PLoS ONE 2015, 10, e0117477. [CrossRef] [PubMed]

68. Rutault, K.; Alderman, C.; Chain, B.M.; Katz, D.R. Reactive oxygen species activate human peripheral blood dendritic cells. Free Radic. Biol. Med. 1999, 26, 232-238. [CrossRef]

69. Yang, J.; Yang, X.; Zou, H.; Li, M. Oxidative Stress and Treg and Th17 Dysfunction in Systemic Lupus Erythematosus. Oxidative Med. Cell. Longev. 2016, 2016, 2526174. [CrossRef]

70. Delgoffe, G.M.; Pollizzi, K.N.; Waickman, A.T.; Heikamp, E.; Meyers, D.J.; Horton, M.R.; Xiao, B.; Worley, P.F.; Powell, J.D. The kinase $\mathrm{mTOR}$ regulates the differentiation of helper $\mathrm{T}$ cells through the selective activation of signaling by $\mathrm{mTORC} 1$ and mTORC2. Nat. Immunol. 2011, 12, 295-303. [CrossRef]

71. Park, D.; Jeong, H.; Lee, M.N.; Koh, A.; Kwon, O.; Yang, Y.R.; Noh, J.; Suh, P.-G.; Park, H.; Ryu, S.H. Resveratrol induces autophagy by directly inhibiting mTOR through ATP competition. Sci. Rep. 2016, 6, 21772. [CrossRef]

72. Sizzano, F.; Collino, S.; Cominetti, O.; Monti, D.; Garagnani, P.; Ostan, R.; Pirazzini, C.; Bacalini, M.G.; Mari, D.; Passarino, G.; et al. Evaluation of Lymphocyte Response to the Induced Oxidative Stress in a Cohort of Ageing Subjects, including Semisupercentenarians and Their Offspring. Mediat. Inflamm. 2018, 2018, 7109312. [CrossRef] [PubMed]

73. Zabłocka-Słowińska, K.; Płaczkowska, S.; Skórska, K.; Prescha, A.; Pawełczyk, K.; Porębska, I.; Kosacka, M.; Grajeta, H. Oxidative stress in lung cancer patients is associated with altered serum markers of lipid metabolism. PLoS ONE 2019, 14, e0215246. [CrossRef]

74. Hu, L.; Tian, K.; Zhang, T.; Fan, C.-H.; Zhou, P.; Zeng, D.; Zhao, S.; Li, L.-S.; Smith, H.S.; Li, J.; et al. Cyanate Induces Oxidative Stress Injury and Abnormal Lipid Metabolism in Liver through Nrf2/HO-1. Molecules 2019, 24, 3231. [CrossRef] [PubMed]

75. Liaras, K.; Fesatidou, M.; Geronikaki, A. Thiazoles and Thiazolidinones as COX/LOX Inhibitors. Molecules 2018, $23,685$. [CrossRef] [PubMed] 
76. Hao, M.; Jiang, L.; Fang, N.; Pu, J.; Hu, L.; Shen, L.-H.; Song, W.; He, B. The cannabinoid WIN55,212-2 protects against oxidized LDL-induced inflammatory response in murine macrophages. J. Lipid Res. 2010, 51, 2181-2190. [CrossRef]

77. Rajesh, M.; Mukhopadhyay, P.; Haskó, G.; Liaudet, L.; Mackie, K.; Pacher, P. Cannabinoid-1 receptor activation induces reactive oxygen species-dependent and -independent mitogen-activated protein kinase activation and cell death in human coronary artery endothelial cells. Br. J. Pharmacol. 2010, 160, 688-700. [CrossRef]

78. Honda, T.; Segi-Nishida, E.; Miyachi, Y.; Narumiya, S. Prostacyclin-IP signaling and prostaglandin E2-EP2/EP4 signaling both mediate joint inflammation in mouse collagen-induced arthritis. J. Exp. Med. 2006, 203, 325-335. [CrossRef]

79. Tsuboi, K.; Uyama, T.; Okamoto, Y.; Ueda, N. Endocannabinoids and related N-acylethanolamines: Biological activities and metabolism. Inflamm. Regen. 2018, 38, 28. [CrossRef]

80. Matthews, A.T.; Lee, J.H.; Borazjani, A.; Mangum, L.C.; Hou, X.; Ross, M.K. Oxyradical stress increases the biosynthesis of 2-arachidonoylglycerol: Involvement of NADPH oxidase. Am. J. Physiol. Cell Physiol. 2016, 311, C960-C974. [CrossRef]

81. Turner, S.E.; Williams, C.M.; Iversen, L.; Whalley, B.J. Molecular Pharmacology of Phytocannabinoids. Prog. Chem. Org. Nat. Prod. 2017, 103, 61-101. [CrossRef]

82. Atalay, S.; Jarocka-Karpowicz, I.; Skrzydlewska, E. Antioxidative and Anti-Inflammatory Properties of Cannabidiol. Antioxidants 2019, 9, 21. [CrossRef] [PubMed]

83. Atalay, S.; Dobrzyńska, I.; Gegotek, A.; Skrzydlewska, E. Cannabidiol protects keratinocyte cell membranes following exposure to UVB and hydrogen peroxide. Redox Biol. 2020, 36, 101613. [CrossRef] [PubMed]

84. Turcotte, C.; Blanchet, M.-R.; LaViolette, M.; Flamand, N. The CB2 receptor and its role as a regulator of inflammation. Cell. Mol. Life Sci. 2016, 73, 4449-4470. [CrossRef] [PubMed]

85. Gouda, H.M.; Kamel, N.M. Cannabinoid CB2 receptor gene (CNR2) polymorphism is associated with chronic childhood immune thrombocytopenia in Egypt. Blood Coagul. Fibrinolysis 2013, 24, 247-251. [CrossRef]

86. Rossi, F.; Bellini, G.; Tolone, C.; Luongo, L.; Mancusi, S.; Papparella, A.; Sturgeon, C.; Fasano, A.; Nobili, B.; Perrone, L.; et al. The Cannabinoid Receptor type 2 Q63R variant increases the risk of celiac disease: Implication for a novel molecular biomarker and future therapeutic intervention. Pharmacol. Res. 2012, 66, 88-94. [CrossRef]

87. Hohmann, U.; Pelzer, M.; Kleine, J.; Hohmann, T.; Ghadban, C.; Dehghani, F. Opposite Effects of Neuroprotective Cannabinoids, Palmitoylethanolamide, and 2-Arachidonoylglycerol on Function and Morphology of Microglia. Front. Neurosci. 2019, 13, 1180. [CrossRef]

88. Souza, M.C.; Rosas, E.C. Cannabinoid Receptors as Regulators of Neutrophil Activity in Inflammatory Diseases. In Neutrophils; IntechOpen: London, UK, 2018. [CrossRef]

89. Kurihara, R.; Tohyama, Y.; Matsusaka, S.; Naruse, H.; Kinoshita, E.; Tsujioka, T.; Katsumata, Y.; Yamamura, H. Effects of Peripheral Cannabinoid Receptor Ligands on Motility and Polarization in Neutrophil-like HL60 Cells and Human Neutrophils. J. Biol. Chem. 2006, 281, 12908-12918. [CrossRef]

90. Balenga, N.A.B.; Aflaki, E.; Kargl, J.; Platzer, W.; Schröder, R.; Blättermann, S.; Kostenis, E.; Brown, A.J.; Heinemann, A.; Waldhoer, M. GPR55 regulates cannabinoid 2 receptor-mediated responses in human neutrophils. Cell Res. 2011, 21, 1452-1469. [CrossRef]

91. Chiurchiù, V.; Cencioni, M.T.; Bisicchia, E.; Bardi, M.D.; Gasperini, C.; Borsellino, G.; Centonze, D.; Battistini, L.; Maccarrone, M. Distinct modulation of human myeloid and plasmacytoid dendritic cells by anandamide in multiple sclerosis. Ann. Neurol. 2013, 73, 626-636. [CrossRef]

92. Chiurchiù, V.; Battistini, L.; Maccarrone, M. Endocannabinoid signalling in innate and adaptive immunity. Immunology 2015, 144, 352-364. [CrossRef]

93. Smith, S.R.; Terminelli, C.; Denhardt, G. Effects of cannabinoid receptor agonist and antagonist ligands on production of inflammatory cytokines and anti-inflammatory interleukin-10 in endotoxemic mice. J. Pharmacol. Exp. Ther. 2000, 293, 136-150. [PubMed]

94. Jarocka-Karpowicz, I.; Biernacki, M.; Wroński, A.; Gęgotek, A.; Skrzydlewska, E. Cannabidiol Effects on Phospholipid Metabolism in Keratinocytes from Patients with Psoriasis Vulgaris. Biomolecules 2020, 10, 367. [CrossRef] [PubMed]

95. Wójcik, P.; Garley, M.; Wroński, A.; Jabłońska, E.; Skrzydlewska, E. Cannabidiol Modifies the Formation of NETs in Neutrophils of Psoriatic Patients. Int. J. Mol. Sci. 2020, 21, 6795. [CrossRef] [PubMed]

96. Palmieri, B.; Laurino, C.; Vadalà, M. A therapeutic effect of cbd-enriched ointment in inflammatory skin diseases and cutaneous scars. Clin. Ter. 2019, 170, e93-e99. [CrossRef]

97. Richardson, D.; Pearson, R.G.; Kurian, N.; Latif, M.L.; Garle, M.J.; Barrett, D.A.; Kendall, D.A.; Scammell, B.E.; Reeve, A.J.; Chapman, V. Characterisation of the cannabinoid receptor system in synovial tissue and fluid in patients with osteoarthritis and rheumatoid arthritis. Arthritis Res. Ther. 2008, 10, R43. [CrossRef]

98. Kinsey, S.G.; Mahadevan, A.; Zhao, B.; Sun, H.; Naidu, P.S.; Razdan, R.K.; Selley, D.E.; Imad Damaj, M.; Lichtman, A.H. The CB2 cannabinoid receptor-selective agonist O-3223 reduces pain and inflammation without apparent cannabinoid behavioral effects. Neuropharmacology 2011, 60, 244-251. [CrossRef]

99. Fukuda, S.; Kohsaka, H.; Takayasu, A.; Yokoyama, W.; Miyabe, C.; Miyabe, Y.; Harigai, M.; Miyasaka, N.; Nanki, T. Cannabinoid receptor 2 as a potential therapeutic target in rheumatoid arthritis. BMC Musculoskelet. Disord. 2014, 15, 275. [CrossRef] 
100. Al-Kofahi, M.; Omura, S.; Tsunoda, I.; Sato, F.; Becker, F.; Gavins, F.N.E.; Woolard, M.D.; Pattillo, C.; Zawieja, D.; Muthuchamy, M.; et al. IL-1 $\beta$ reduces cardiac lymphatic muscle contraction via COX-2 and PGE2 induction: Potential role in myocarditis. Biomed. Pharmacother. 2018, 107, 1591-1600. [CrossRef]

101. McAdam, B.F.; Mardini, I.A.; Habib, A.; Burke, A.; Lawson, J.A.; Kapoor, S.; Fitzgerald, G.A. Effect of regulated expression of human cyclooxygenase isoforms on eicosanoid and isoeicosanoid production in inflammation. J. Clin. Investig. 2000, 105, 1473-1482. [CrossRef]

102. Gabbs, M.; Leng, S.; Devassy, J.G.; Monirujjaman, M.; Aukema, H.M. Advances in Our Understanding of Oxylipins Derived from Dietary PUFAs. Adv. Nutr. 2015, 6, 513-540. [CrossRef]

103. Marone, G.; Galdiero, M.R.; Pecoraro, A.; Pucino, V.; Criscuolo, G.; Triassi, M.; Varricchi, G. Prostaglandin D2receptor antagonists in allergic disorders: Safety, efficacy, and future perspectives. Expert Opin. Investig. Drugs 2019, 28, 73-84. [CrossRef] [PubMed]

104. Ghandour, R.A.; Giroud, M.; Vegiopoulos, A.; Herzig, S.; Ailhaud, G.; Amri, E.-Z.; Pisani, D.F. IP-receptor and PPARs trigger the conversion of human white to brite adipocyte induced by carbaprostacyclin. Biochim. Biophys. Acta 2016, 1861, 285-293. [CrossRef] [PubMed]

105. Huang, H.; Aladelokun, O.; Ideta, T.; Giardina, C.; Ellis, L.M.; Rosenberg, D.W. Inhibition of PGE 2/EP4 receptor signaling enhances oxaliplatin efficacy in resistant colon cancer cells through modulation of oxidative stress. Sci. Rep. 2019, 9, 4954. [CrossRef] [PubMed]

106. Sales, K.; Boddy, S.; Jabbour, H. F-prostanoid receptor alters adhesion, morphology and migration of endometrial adenocarcinoma cells. Oncogene 2008, 27, 2466-2477. [CrossRef]

107. Elhassanny, A.E.M.; Ladin, D.A.; Soliman, E.; Albassam, H.; Morris, A.; Kobet, R.; Thayne, K.; Burns, C.; Danell, A.S.; Van Dross, R. Prostaglandin D2-ethanolamide induces skin cancer apoptosis by suppressing the activity of cellular antioxidants. Prostaglandins Other Lipid Mediat. 2019, 142, 9-23. [CrossRef]

108. Kaliński, P.; Hilkens, C.M.; Snijders, A.; Snijdewint, F.G.; Kapsenberg, M.L. IL-12-deficient dendritic cells, generated in the presence of prostaglandin E2, promote type 2 cytokine production in maturing human naive T helper cells. J. Immunol. 1997, $159,28-35$.

109. Muthuswamy, R.; Mueller-Berghaus, J.; Haberkorn, U.; Reinhart, T.A.; Schadendorf, D.; Kalinski, P. PGE(2) transiently enhances DC expression of CCR7 but inhibits the ability of DCs to produce CCL19 and attract naive T cells. Blood 2010, 116, 1454-1459. [CrossRef]

110. Joo, M.; Sadikot, R.T. PGD Synthase and PGD2 in Immune Resposne. Mediat. Inflamm. 2012, 2012, 1-6. [CrossRef]

111. Moalli, F.; Cupovic, J.; Thelen, F.; Halbherr, P.; Fukui, Y.; Narumiya, S.; Ludewig, B.; Stein, J.V. Thromboxane A2 acts as tonic immunoregulator by preferential disruption of low-avidity CD4+ T cell-dendritic cell interactions. J. Exp. Med. 2014, 211, 2507-2517. [CrossRef]

112. Nagamachi, M.; Sakata, D.; Kabashima, K.; Furuyashiki, T.; Murata, T.; Segi-Nishida, E.; Soontrapa, K.; Matsuoka, T.; Miyachi, Y.; Narumiya, S. Facilitation of Th1-mediated immune response by prostaglandin E receptor EP1. J. Exp. Med. 2007, 204, 2865-2874. [CrossRef]

113. Boniface, K.; Bak-Jensen, K.S.; Li, Y.; Blumenschein, W.M.; McGeachy, M.J.; McClanahan, T.K.; McKenzie, B.S.; Kastelein, R.A.; Cua, D.J.; de Waal Malefyt, R. Prostaglandin E2 regulates Th17 cell differentiation and function through cyclic AMP and EP2/EP4 receptor signaling. J. Exp. Med. 2009, 206, 535-548. [CrossRef] [PubMed]

114. Razali, N.; Hohjoh, H.; Inazumi, T.; Maharjan, B.D.; Nakagawa, K.; Konishi, M.; Sugimoto, Y.; Hasegawa, H. Induced Prostanoid Synthesis Regulates the Balance between Th1- and Th2-Producing Inflammatory Cytokines in the Thymus of Diet-Restricted Mice. Biol. Pharm. Bull. 2020, 43, 649-662. [CrossRef] [PubMed]

115. Bernard, M.P.; Phipps, R.P. Inhibition of cyclooxygenase-2 impairs the expression of essential plasma cell transcription factors and human B-lymphocyte differentiation. Immunology 2010, 129, 87-96. [CrossRef] [PubMed]

116. Wang, J.; Zhang, L.; Kang, D.; Yang, D.; Tang, Y. Activation of PGE2/EP2 and PGE2/EP4 signaling pathways positively regulate the level of PD-1 in infiltrating CD8+ T cells in patients with lung cancer. Oncol. Lett. 2018, 15, 552-558. [CrossRef]

117. Epp, N.; Frstenberger, G.; Mller, K.; De Juanes, S.; Leitges, M.; Hausser, I.; Thieme, F.; Liebisch, G.; Schmitz, G.; Krieg, P. 12R-lipoxygenase deficiency disrupts epidermal barrier function. J. Cell Biol. 2007, 177, 173-182. [CrossRef]

118. Mayatepek, E.; Hoffmann, G.F. Leukotrienes: Biosynthesis, Metabolism, and Pathophysiologic Significance. Pediatr. Res. 1995, 37, 1-9. [CrossRef]

119. Bacon, K.B.; Camp, R.D.; Cunningham, F.M.; Woollard, P.M. Contrasting in vitro lymphocyte chemotactic activity of the hydroxyl enantiomers of 12-hydroxy-5,8,10,14-eicosatetraenoic acid. Br. J. Pharmacol. 1988, 95, 966-974. [CrossRef] [PubMed]

120. Cai, Y.; Kumar, R.K.; Zhou, J.; Foster, P.S.; Webb, D.C. Ym1/2 Promotes Th2 Cytokine Expression by Inhibiting 12/15(S)Lipoxygenase: Identification of a Novel Pathway for Regulating Allergic Inflammation. J. Immunol. 2009, 182, 5393-5399. [CrossRef] [PubMed]

121. Liu, M.; Yokomizo, T. The role of leukotrienes in allergic diseases. Allergol. Int. 2015, 64, 17-26. [CrossRef] [PubMed]

122. Fan, H.W.; Liu, G.Y.; Zhao, C.F.; Li, X.F.; Yang, X.Y. Differential expression of COX-2 in osteoarthritis and rheumatoid arthritis. Genet. Mol. Res. 2015, 14, 12872-12879. [CrossRef]

123. Zhang, L.; Bertucci, A.M.; Smith, K.A.; Xu, L.; Datta, S.K. Hyperexpression of cyclooxygenase 2 in the lupus immune system and effect of cyclooxygenase 2 inhibitor diet therapy in a murine model of systemic lupus erythematosus. Arthritis Rheum. 2007, 56, 4132-4141. [CrossRef] 
124. Pellefigues, C.; Dema, B.; Lamri, Y.; Saidoune, F.; Chavarot, N.; Lohéac, C.; Pacreau, E.; Dussiot, M.; Bidault, C.; Marquet, F.; et al. Prostaglandin D2 amplifies lupus disease through basophil accumulation in lymphoid organs. Nat. Commun. 2018, 9, 1-14. [CrossRef]

125. Fattahi, M.J.; Mirshafiey, A. Prostaglandins and Rheumatoid Arthritis. Arthritis 2012, 2012, 1-7. [CrossRef]

126. Clark, P.; Rowland, S.E.; Denis, D.; Mathieu, M.-C.; Stocco, R.; Poirier, H.; Burch, J.; Han, Y.; Audoly, L.; Therien, A.G.; et al. MF498 [N-\{[4-(5,9-Diethoxy-6-oxo-6,8-dihydro-7H-pyrrolo[3,4-g]quinolin-7-yl)-3-methylbenzyl]sulfonyl\}-2-(2-methoxyphenyl)acetamide], a Selective E Prostanoid Receptor 4 Antagonist, Relieves Joint Inflammation and Pain in Rodent Models of Rheumatoid and Osteoarthritis. J. Pharmacol. Exp. Ther. 2008, 325, 425-434. [CrossRef] [PubMed]

127. Wu, M.-Y.; Lin, T.-H.; Chiu, Y.-C.; Liou, H.-C.; Yang, R.-S.; Fu, W.-M. Involvement of 15-lipoxygenase in the inflammatory arthritis. J. Cell. Biochem. 2012, 113, 2279-2289. [CrossRef]

128. Gheorghe, K.R.; Korotkova, M.; Catrina, A.I.; Backman, L.; Klint, E.A.; Claesson, H.-E.; Rådmark, O.; Jakobsson, P.-J. Expression of 5-lipoxygenase and 15-lipoxygenase in rheumatoid arthritis synovium and effects of intraarticular glucocorticoids. Arthritis Res. Ther. 2009, 11, R83. [CrossRef] [PubMed]

129. Bauer, J.; Ripperger, A.; Frantz, S.; Ergün, S.; Schwedhelm, E.; Benndorf, R.A. Pathophysiology of isoprostanes in the cardiovascular system: Implications of isoprostane-mediated thromboxane A2 receptor activation. Br. J. Pharmacol. 2014, 171, 3115-3131. [CrossRef] [PubMed]

130. Łuczaj, W.; Gęgotek, A.; Skrzydlewska, E. Antioxidants and HNE in redox homeostasis. Free Radic. Biol. Med. 2017, 111, 87-101. [CrossRef]

131. Gegotek, A.; Skrzydlewska, E. Biological effect of protein modifications by lipid peroxidation products. Chem. Phys. Lipids 2019, 221, 46-52. [CrossRef]

132. Ye, Y.; Wu, T.; Zhang, T.; Han, J.; Habazi, D.; Saxena, R.; Mohan, C. Elevated oxidized lipids, anti-lipid autoantibodies and oxidized lipid immune complexes in active SLE. J. Clin. Immunol. 2019, 205, 43-48. [CrossRef]

133. Wang, Y.; Wang, W.; Yang, H.; Shao, D.; Zhao, X.; Zhang, G. Intraperitoneal injection of 4-hydroxynonenal (4-HNE), a lipid peroxidation product, exacerbates colonic inflammation through activation of Toll-like receptor 4 signaling. Free Radic. Biol. Med. 2019, 131, 237-242. [CrossRef] [PubMed]

134. Jang, E.J.; Kim, D.H.; Lee, B.; Lee, E.K.; Chung, K.W.; Moon, K.M.; Kim, M.J.; An, H.J.; Jeong, J.W.; Kim, Y.R.; et al. Activation of proinflammatory signaling by 4-hydroxynonenal-Src adducts in aged kidneys. Oncotarget 2016, 7, 50864-50874. [CrossRef] [PubMed]

135. Yin, G.; Wang, Y.; Cen, X.-M.; Yang, M.; Liang, Y.; Xie, Q.-B. Lipid Peroxidation-Mediated Inflammation Promotes Cell Apoptosis through Activation of NF-kB Pathway in Rheumatoid Arthritis Synovial Cells. Mediat. Inflamm. 2015, 2015, 460310. [CrossRef]

136. Gegotek, A.; Domingues, P.; Wroński, A.; Wójcik, P.; Skrzydlewska, E. Proteomic plasma profile of psoriatic patients. J. Pharm. Biomed. Anal. 2018, 155, 185-193. [CrossRef]

137. Gegotek, A.; Domingues, P.; Wroński, A.; Ambrożewicz, E.; Skrzydlewska, E. The Proteomic Profile of Keratinocytes and Lymphocytes in Psoriatic Patients. Proteom. Clin. Appl. 2019, 13, 1800119. [CrossRef]

138. Karabowicz, P.; Wroński, A.; Ostrowska, H.; Waeg, G.; Zarkovic, N.; Skrzydlewska, E. Reduced Proteasome Activity and Enhanced Autophagy in Blood Cells of Psoriatic Patients. Int. J. Mol. Sci. 2020, 21, 7608. [CrossRef]

139. Akgöl, G.; Ulusoy, H.; Telo, S.; Gülkesen, A.; Yildirim, T.; Poyraz, A.K.; Kaya, A. Is 4-Hydroxynonenal a Predictive Parameter for the Development of Joint Erosion in Patients With Rheumatoid Arthritis? Arch. Rheumatol. 2016, 31, 76-81. [CrossRef]

140. Luczaj, W.; Jarocka-Karpinska, I.; Sierakowski, S.; Andrisic, L.; Zarkovic, N.; Skrzydlewska, E. Lipid peroxidation in Rheumatoid arthritis; consequences and monitoring. Free Radic. Biol. Med. 2014, 75 (Suppl. 1), S49. [CrossRef]

141. Shah, D.; Mahajan, N.; Sah, S.; Nath, S.K.; Paudyal, B. Oxidative stress and its biomarkers in systemic lupus erythematosus. J. Biomed. Sci. 2014, 21, 23. [CrossRef]

142. Grönwall, C.; Amara, K.; Hardt, U.; Krishnamurthy, A.; Steen, J.; Engström, M.; Sun, M.; Ytterberg, A.J.; Zubarev, R.A.; Scheel-Toellner, D.; et al. Autoreactivity to malondialdehyde-modifications in rheumatoid arthritis is linked to disease activity and synovial pathogenesis. J. Autoimmun. 2017, 84, 29-45. [CrossRef]

143. Leitinger, N.; Huber, J.; Rizza, C.; Mechtcheriakova, D.; Bochkov, V.; Koshelnick, Y.; Berliner, J.A.; Binder, B.R. The isoprostane 8-iso-PGF(2alpha) stimulates endothelial cells to bind monocytes: Differences from thromboxane-mediated endothelial activation. FASEB J. 2001, 15, 1254-1256. [CrossRef] [PubMed]

144. Zahler, S.; Becker, B.F. Indirect enhancement of neutrophil activity and adhesion to cultured human umbilical vein endothelial cells by isoprostanes (iPF2alpha-III and iPE2-III). Prostaglandins Other Lipid Mediat. 1999, 57, 319-331. [CrossRef]

145. Scholz, H.; Yndestad, A.; Damås, J.K.; Wæhre, T.; Tonstad, S.; Aukrust, P.; Halvorsen, B. 8-Isoprostane increases expression of interleukin-8 in human macrophages through activation of mitogen-activated protein kinases. Cardiovasc. Res. 2003, 59, 945-954. [CrossRef]

146. Milne, G.L.; Yin, H.; Hardy, K.D.; Davies, S.S.; Roberts, L.J. Isoprostane Generation and Function. Chem. Rev. 2011, 111, 5973-5996. [CrossRef]

147. Carlström, K.E.; Ewing, E.; Granqvist, M.; Gyllenberg, A.; Aeinehband, S.; Enoksson, S.L.; Checa, A.; Badam, T.V.S.; Huang, J.; Gomez-Cabrero, D.; et al. Therapeutic efficacy of dimethyl fumarate in relapsing-remitting multiple sclerosis associates with ROS pathway in monocytes. Nat. Commun. 2019, 10, 3081. [CrossRef] 